NBER WORKING PAPER SERIES

\title{
FROM GREAT DEPRESSION TO GREAT CREDIT CRISIS: SIMILARITIES, DIFFERENCES AND LESSONS
}

\author{
Miguel Almunia \\ Agustín S. Bénétrix \\ Barry Eichengreen \\ Kevin H. O'Rourke \\ Gisela Rua \\ Working Paper 15524 \\ http://www.nber.org/papers/w15524
}

\author{
NATIONAL BUREAU OF ECONOMIC RESEARCH \\ 1050 Massachusetts Avenue \\ Cambridge, MA 02138
}

November 2009

This paper was presented at the 50th Economic Policy Panel Meeting, held in Tilburg on October 23-24, 2009. The authors thank the University of Tilburg for their generosity in hosting the meeting. This paper is produced as part of the project 'Historical Patterns of Development and Underdevelopment: Origins and Persistence of the Great Divergence (HI-POD),' a Collaborative Project funded by the European Commission's Seventh Research Framework Programme, Contract number 225342. Financial assistance was also received from the Coleman Fung Risk Management Center at the University of California, Berkeley. This paper could not have been written without the generosity of many colleagues who have shared their data with us. We are extremely grateful to Richard Baldwin, Giovanni Federico, Vahagn Galstyan, Mariko Hatase, Pierre-Cyrille Hautcoeur, William Hynes, Doug Irwin, Lars Jonung, Philip Lane, Sibylle Lehmann, Ilian Mihov, Emory Oakes, Albrecht Ritschl, Lennart Schön, Pierre Sicsic, Wim Suyker, Alan Taylor, Bryan Taylor, Gianni Toniolo, Irina Tytell, the staff at the National Library of Ireland, two anonymous referees, and the editor, Philippe Martin. The views expressed herein are those of the author(s) and do not necessarily reflect the views of the National Bureau of Economic Research.

NBER working papers are circulated for discussion and comment purposes. They have not been peerreviewed or been subject to the review by the NBER Board of Directors that accompanies official NBER publications.

(C) 2009 by Miguel Almunia, Agustín S. Bénétrix, Barry Eichengreen, Kevin H. O'Rourke, and Gisela Rua. All rights reserved. Short sections of text, not to exceed two paragraphs, may be quoted without explicit permission provided that full credit, including $(\odot)$ notice, is given to the source. 
From Great Depression to Great Credit Crisis: Similarities, Differences and Lessons

Miguel Almunia, Agustín S. Bénétrix, Barry Eichengreen, Kevin H. O'Rourke, and Gisela

Rua

NBER Working Paper No. 15524

November 2009

JEL No. E63,F16,N10,N27

\begin{abstract}
The Great Depression of the 1930s and the Great Credit Crisis of the 2000s had similar causes but elicited strikingly different policy responses. It may still be too early to assess the effectiveness of current policy responses, but it is possible to analyze monetary and fiscal policies in the 1930s as a "natural experiment" or "counterfactual" capable of shedding light on the impact of recent policies. We employ vector autoregressions, instrumental variables, and qualitative evidence for a panel of 27 countries in the period 1925-1939. The results suggest that monetary and fiscal stimulus was effective - that where it did not make a difference it was not tried. The results also shed light on the debate over fiscal multipliers in episodes of financial crisis. They are consistent with multipliers at the higher end of those estimated in the recent literature, consistent with the idea that the impact of fiscal stimulus will be greater when banking system are dysfunctional and monetary policy is constrained by the zero bound.
\end{abstract}

Miguel Almunia

Department of Economics

University of California, Berkeley

malmunia@econ.berkeley.edu

Agustín S. Bénétrix

Department of Economics and IIIS

Trinity College

Dublin

benetria@tcd.ie

Barry Eichengreen

Department of Economics

University of California, Berkeley

549 Evans Hall 3880

Berkeley, CA 94720-3880

and NBER

eichengr@econ.Berkeley.edu
Kevin H. O'Rourke

Department of Economics and IIIS

Trinity College

Dublin 2, IRELAND

and NBER

kevin.orourke@tcd.ie

Gisela Rua

Department of Economics

University of California, Berkeley

grua@econ.berkeley.edu 


\section{Introduction}

The parallels between the Great Credit Crisis of 2008 and the onset of the Great Depression have been widely commented upon. Paul Krugman posted to his widely-read blog a graph comparing the fall in manufacturing production in the United States from its respective mid-1929 and late-2007 peaks. ${ }^{1}$ The "Bad Bears” graph comparing the stock market crashes of 1929-30 and 2008-9 has had wide circulation. ${ }^{2}$ Justin Fox has prominently compared the behaviour of payroll employment in the two downturns. ${ }^{3}$

But these authors, like most other commentators, compared the United States then and now, reflecting the fact that the U.S. has been extensively studied and the relevant economic statistics are at hand. This, however, yields a misleading picture. The United States is not the world. The Great Depression and the Great Credit Crisis, even if they both in some sense originated in the United States, were and are global phenomena. ${ }^{4}$ The Great Depression was transmitted internationally through trade flows, capital flows and commodity prices. That said, different countries were affected differently depending on their circumstances and policies. Some, France for example, were largely passive, while others, such as Japan, made aggressive use of both monetary and fiscal policies. The United States is not representative of their experiences.

The Great Credit Crisis is just as global. Indeed, starting in the spring of 2008 events took an even graver turn outside the United States, with even larger falls in other countries in manufacturing production, exports, and equity prices. ${ }^{5}$ Similarly, different countries have

\footnotetext{
${ }^{1}$ Paul Krugman, “The Great Recession versus the Great Depression,” Conscience of a Liberal (20 March 2009), http://krugman.blogs.nytimes.com/2009/03/20/the-great-recession-versus-the-great-depression/ 2 Doug Short, "Four Bad Bears,” DShort: Financial Lifecycle Planning (20 March 2009), http://dshort.com/ 3 Justin Fox, "On the Job Front this is No Great Depression,” The Curious Capitalist (16 March 2009), http://curiouscapitalist.blogs.time.com/2009/03/16/on-the-job-front-this-is-no-great-depression-not-even-close/. More recently there has been a comparison of the 1930s and now, again focusing on the United States, in IMF (2009) and Helbling (2009).

${ }^{4}$ While the early literature on the Depression was heavily U.S. based, modern scholarship emphasizes its international aspects (Temin 1989, Eichengreen 1992, Bernanke 2000).

${ }^{5}$ Although this is not so for each and every economy.
} 
responded differently to the crisis, notably with different monetary and fiscal policies, some more aggressive, others less.

In this paper we fill in the global picture of the two downturns. We show that the decline in manufacturing globally in the twelve months following the global peak in industrial production, which we place in early 2008, was as severe as in the twelve months following the peak in $1929 .{ }^{6}$ Similarly, while the fall in the U.S. stock market paralleled 1929 during the first year of the crisis, global stock markets fell even faster than 80 years ago. Another respect where the Great Credit Crisis initially "surpassed” the Great Depression was in destroying trade. World trade fell even faster in the first year of this crisis than in 1929-30, an alarming observation given the prominence in the historical literature of trade destruction as a factor compounding the Great Depression.

At the same time, the response of monetary and fiscal policies, not just in the United States but globally, was quicker and stronger this time. At the time of writing (October 2009), it would appear that global industrial production and trade have stabilized. ${ }^{7}$ The question is how much credit to give to monetary and fiscal policies. This too is something on which comparisons with the 1930s may shed light.

Section 2 of the paper puts more flesh on these comparative bones, after which Section 3 compares the policy response to the two crises. The key question is whether the different policy responses in fact are responsible for the different macroeconomic outcomes. To begin to answer this we assess the 1930s policy response, asking: what did governments do to combat the Depression? And had they done more, would it have been effective?

\footnotetext{
${ }^{6}$ Here, then, is an illustration of how the global picture provides a different perspective; the U.S. case considered by Krugman found no such thing. Since our perspective is global rather than American, throughout this paper we look at movements in output following the global (rather than the U.S.) peaks in industrial production. Specifically we place these at June 1929 and April 2008.

${ }^{7}$ Although some forecasters point to the possibility of a double-dip recession.
} 
There is much at stake. It has been argued that fiscal policy is unlikely to boost output today because it didn’t work in the 1930s. Similarly, it is argued that monetary policy is likely to be impotent in the near-zero-interest-rate liquidity-trap-like conditions of 2009 because it didn't work in the liquid-trap-like conditions of the 1930s. But, as we show, fiscal policy, where applied, worked extremely well in the 1930s, whether because spending from other sources was limited by uncertainty and liquidity constraints, or because with interest rates close to the zero bound there was little crowding out of private spending. Previous studies have not found an effect of fiscal policy in the 1930s, not because it was ineffectual, but because it was hardly tried (the magnitude of the fiscal impulse was small). ${ }^{8}$ That said, we still find it possible to pick out an effect. Our results for monetary policy are mixed, but we again find some evidence that expansionary policies were effective in stimulating activity. That modern studies (see e.g. IMF 2009) have not found equally strong effects in crisis countries, where the existence of dysfunctional banking systems and liquidity-trap-like conditions casts doubts on the potency of monetary policy, appears to reflect the fact that the typical post-1980s financial crisis did not occur in a deflationary environment like the 1930s or like that through which countries have been suffering in the last year. The role of monetary policy was to vanquish these deflationary expectations, something that was crucially important then as well as now. ${ }^{9}$

\section{The Depression and Credit Crisis Compared}

Figure 1 shows the standard US industrial output indices for the two periods. ${ }^{10}$ The solid line tracks industrial output from its US peak in July 1929, while the dotted line tracks output from its US peak in December 2007. While US industrial output fell steeply, it did not

\footnotetext{
${ }^{8}$ To generalize E. Cary Brown's famous conclusion for the United States. To quote, fiscal policy in the U.S. was unimportant "not because it did not work, but because it was not tried” (Brown 1956, pp. 863-6).

${ }^{9}$ A point that has been made recently by Eggertsson (2008) for the United States and further generalized here.

${ }^{10}$ These are the same data on US monthly industrial production used by Krugman (cited above), drawn from the website of the Federal Reserve Bank of St. Louis. Source:

http://research.stlouisfed.org/fred2/series/INDPRO/downloaddata?rid=13.
} 
fall as rapidly as after June 1929. The logical conclusion is that the crisis facing the economy last spring, while severe, was no Great Depression. "Half a Great Depression” is how Krugman put it.

We now show that this U.S.-centric view is too optimistic. Figure 2 compares movements in global industrial output during the two crises. ${ }^{11}$ Since we are interested in the extent to which world industrial output declined during the two periods, we plot the two indices from their global peaks, which we place in June 1929 and April 2008. ${ }^{12}$ As can be seen, in the first year of the crisis, global industrial production fell about as fast as in the first year of the Great Depression. ${ }^{13}$ It then appears to bottom out in the spring and has since shown signs of recovery. This is in contrast with the Depression: while there were two periods of recovery (the second of which, in 1931, was fairly substantial), output fell on average for three successive years.

A distinction between today and 80 years ago concerns the location of industrial production and thus the location of falling industrial output. Eight decades ago, industry was

\footnotetext{
${ }^{11}$ The recent data are from the IMF, while the interwar data come from two sources. Up to and including September 1932, they are from Rolf Wagenführ’s study of world industrial output from 1860 to 1932 undertaken in the Institut für Konjunkturforschung, Berlin. In addition to compiling numerous national indices, Wagenführ (1933) also provides world industrial output indices (Table 7, p. 68). After September 1932, these series are spliced onto an index of world industrial output subsequently produced at the Institut für Konjunkturforschung and published in Vierteljahrshefte zur Konjunkturforschung and Statistik des In-ind Auslands. The Institut für Konjunkturforschung is coy about how it derived its index, but one can assume that it is a weighted average of country-specific monthly indices for those countries which produced them at the time, and which were largely (but not exclusively) to be found in Europe and North America. Fortunately, European market economies, plus Canada, the United States and Japan, accounted for $80.3 \%$ of world industrial output in 1928, while developed countries as a whole (including planned economies such as the USSR) accounted for 92.8 per cent. See Bairoch (1982), p. 304. One can thus be reasonably confident that these indices reflect interwar world trends fairly accurately. If there is a bias in either direction, it is probably to make the interwar contraction seem worse than it actually was, since the peripheral economies for which data were unavailable at the time were in many cases industrializing rapidly, as a result of the breakdown of international trade. This is certainly the judgment of Hilgerdt (League of Nations 1945, p. 127), and the implication is that if anything Figure 2 casts the interwar period in too gloomy a light, and consequently our own in too flattering a light.

${ }^{12}$ We stress that we are not attempting to date the world business cycle peaks in either episode. Our only concern is to compare the extent to which output declined during the two episodes, and it makes sense to measure these declines from the months in which output peaked.

${ }^{13}$ The comparison is less favourable to the interwar period if Stalin's rapidly industrializing Soviet Union is excluded. Either way, however, the statement in the text follows.
} 
far more concentrated in Europe and North America. ${ }^{14}$ It was industrial production that disproportionately collapsed, and it was therefore in Europe and North America where output and employment were disproportionately affected. Back then international trade still largely took the form of the exchange of northern industrial goods for southern primary products, reflecting the international division of labour that emerged following the Industrial Revolution (Findlay and O’Rourke 2007). Since when the Depression struck it was above all industrial output that collapsed (Figure 3), output in Latin America, Asia and the rest of the developing world, where agriculture and other primary production dominated, was more stable. Similarly, international trade in manufactured goods fell far more rapidly than trade in primary products (Figure 4). Given world trade patterns, this translated into a deterioration in Southern terms of trade, as primary commodity prices fell even more rapidly than the prices of manufactures. This was a key mechanism lowering incomes in the south despite its more stable output. (Something similar happened in the oil-producing economies during the 20089 crisis.)

Today, by contrast, industry has spread around the world, and as a result output fell rapidly everywhere in the first year of the crisis. ${ }^{15}$

Overall, then, industrial output fell as fast in the first twelve months starting in April 2008 as it did in the early stages of the Great Depression. It might be argued that the initial decline should not be regarded as so alarming because industry accounts for a smaller share of GDP and employment today than it did 80 years ago. While this may be true for early industrializers like Britain, France, Germany and the United States, it is not true for later European industrializers like Finland, Hungary, Ireland, Poland and Portugal. ${ }^{16}$ It is even less

\footnotetext{
${ }^{14}$ See footnote 11.

15 This also has important implications for understanding the collapse of trade, as we shall see.

${ }^{16}$ Compare Buyst and Franaszek (2009) and OECD (2009a).
} 
true for the world as a whole, given the rapid industrialization that has characterized much of the developing world over the last half century. ${ }^{17}$

What of trade? The League of Nations’ Monthly Bulletin provides quarterly data on the volume ("quantum”) of world trade."18 This declined by 36 per cent between the fourth quarter of 1929 and the third quarter of $1932 .{ }^{19}$ Figure 5 shows this series, interpolated geometrically to form a monthly series, together with the monthly volume of world trade series produced by the Netherlands Bureau for Economic Policy Analysis. ${ }^{20}$ As can be seen, world trade fell much more rapidly in the first year of the recent crisis than at the comparable stage of the Great Depression. It fell by almost 20 per cent in the nine months from April 2008 through January 2009, or by more than half as much as during the three full years 192932. It then stabilized, falling only very modestly over the succeeding four months, before increasing moderately in June and vigorously in July.

Several explanations have been offered for the greater elasticity of trade with respect to production in the current crisis, including the growth in vertical specialization (Yi 2008, Freund 2009, Tanaka 2009) and the difficulty of obtaining trade finance during the credit crunch (Auboin 2009a,b). Both are problematic. Evidence of first-order effects from disruptions to the provision of trade credit is minimal (recall that the multilaterals and

\footnotetext{
${ }^{17}$ We do not have the monthly or quarterly world GDP data which would allow us to compare the movement of world GDP during the two crises. Nor do we yet have annual data for both 2008 and 2009. On the other hand, the IMF forecast in October that global GDP would shrink by 1.1\%. Crucially, this forecast takes account not just of the size of the shock facing the world economy, but of the policy response to the crisis, which as we will see is much more aggressive than the response after 1929. In comparison, between 1929 and 1930, the US economy (which had accounted for a quarter of world GDP in 1929) shrank by 8.9\%, and the world economy thus shrank by $2.9 \%$. Excluding the US, the world economy shrank by just 1\% between 1929 and 1930 . The 'world' here is comprised of the 65 countries for which Maddison (2009) provides data for both years. Note that this sample of countries excludes all of Africa, all of the Middle East bar Turkey, and many other developing countries besides. If they were included, the weight of the US in the world GDP figure would decline, and the size of the 1930 world GDP contraction with it.

${ }^{18}$ That is, the gold value of trade divided by an index of the gold prices of those commodities being traded.

19 The famous cobweb diagram showing that world trade contracted by 69\% between April 1929 and February 1933 plotted movements in the nominal value of world trade, but then as now, the nominal value of trade was largely driven by falling prices (Francois and Woerz 2009).

20 Available at http://www.cpb.nl/eng/research/sector2/data/trademonitor.html.
} 
national export-import banks stepped in quickly with emergency credits). ${ }^{21}$ And while the growth of vertical specialization can explain a greater absolute decline in trade in the crisis, it cannot on its own explain why there was a greater percentage decline or a greater elasticity of trade with respect to production. ${ }^{22}$

We would point to a more straightforward explanation, namely the changing composition of trade. In 192944 per cent of world merchandise trade involved manufactured goods (United Nations 1962, Table 1), a proportion that had increased to 70 per cent in 2007..$^{23}$ As we saw earlier, manufacturing is more volatile than the rest of the economy, and it was output of and trade in manufactures, rather than primary products, that collapsed in the Depression.

Figure 6 explores the impact of this changing composition. The series labelled '1929 weights' is a weighted average of the series on trade in manufactures and non-manufactures plotted in Figure 4 (the weights being the share of the two groupings in total trade in 1929). Not surprisingly this yields a decline in world trade after 1929 that is close to that actually experienced (6 per cent in 1930 versus the 7.5 per cent actually experienced). The series labelled ‘2007 weights’ replaces 1929 weights (44 per cent for manufactures) with 2007 weights (70 per cent for manufactures). It suggests that if manufacturing and nonmanufacturing trade declined at the rate they actually did after 1929, but if manufacturing had been as important a share of world trade as it is today, then total world trade would have

\footnotetext{
21 See however Amiti and Weinstein (2009), which matches Japanese exporters to the banks which provide them with trade credit and finds a strong link between the financial health of these banks and firm export growth.

${ }^{22}$ The point is a simple one: the extra trade implied by vertical disintegration shows up not just in the numerator (the absolute decline in trade), but in the denominator as well (the total initial volume of trade). On the other hand, vertical disintegration could help to explain the higher elasticity of trade with respect to GDP that we are experiencing today, providing that (a) marginal trade disproportionately involves vertically disintegrated goods; and (b) not all trade is vertically disintegrated. See http://www.irisheconomy.ie/index.php/2009/06/18/collapsing-trade-in-a-barbie-world/ for some simple thought experiments.

${ }^{23}$ International Trade Statistics 2008, table II.6, available at http://www.wto.org/english/res_e/statis_e/its2008_e/section2_e/ii06.xls.
} 
fallen much more sharply - by 10 per cent in 1930, comparable to the decline which the WTO is currently predicting for world trade in $2009 .^{24}$

Figure 7 looks finally at global equity markets then and now. ${ }^{25}$ At the global level stock markets plunged even faster in the first year of the recent crisis than in the early stages of the Great Depression. To put the rally that began in March 2009 in perspective, so far it has only put us back on track with the comparable stage of the Depression.

In sum, policy makers were right to be alarmed in early 2009. When viewed as a global phenomenon, the current economic crisis was a Depression-sized event. Since then conditions have stabilized, or so it would appear. The question is whether policy gets the credit.

\section{The Policy Response}

To answer this question, it helps to begin with some facts about the policy responses to the two crises. Two things stand out in the comparison of the policy rates of the major central banks in Figure 8. First, the extremely aggressive rate cuts of the Bank of England and the Fed beginning in late 2008, along with initially less aggressive moves by the ECB. Second, how Germany, Japan, the U.K. and the U.S. raised interest rates in 1931-2 in a perverse attempt to defend their currencies. ${ }^{26}$ Figure 9 shows a GDP-weighted average of central bank discount rates for these five countries plus Poland and Sweden. ${ }^{27}$ As can be seen,

\footnotetext{
${ }^{24}$ Note that while this argument can help to explain the severity of today's world trade collapse relative to that of the Great Depression, it will have much less traction in explaining the growth in the elasticity of trade with respect to output over the past two or three decades, which is the focus of Freund (2009).

${ }^{25}$ Using the Global Financial Database world price index.

${ }^{26}$ Efforts that collapsed with devaluation in Britain and Japan and the imposition of exchange controls in Germany in the third quarter of that year, and with U.S. abandonment of the gold standard some 18 months later.

27 Discount rates are taken from Bernanke and Mihov (2000) for the interwar periods, and from the relevant central bank websites for today (see Appendix 1). The GDP data used in the weighted averages are taken from Maddison (2009), and refer to 1929 and 2006 (the latest year for which he provides data).
} 
in both crises there was a lag of five or six months before discount rates responded to the downturn, but in the present crisis rates have been cut more rapidly. ${ }^{28}$

Figure 10 shows money supplies for a GDP-weighted average of 17 countries accounting for half of world GDP in $2004 .{ }^{29}$ Although it can be argued that permissive monetary policy helping to set the stage for subsequent difficulties was a factor on both occasions, monetary expansion was much more rapid in 2005-08 than in 1925-29. More importantly for present purposes, money supplies continued to grow rapidly in 2008, unlike in 1929 when they levelled off before commencing a rapid decline.

Figure 11 is the analogous picture for the fiscal balance as a percent of GDP. ${ }^{30}$ While governments also ran budget deficits of some magnitude after 1929 (whether or not they wanted to, the collapse of revenues often leaving no choice), the willingness to do so today is greater. Figure 11 also documents that the advanced economies have made the most aggressive use of fiscal policy in the current crisis. But emerging markets, as well, are using fiscal policy more aggressively than the world as a whole in the 1930s.

Recent literature has stressed the exchange rate regime as shaping the policy response. In the current crisis, the major economies were all on flexible exchange rates, which gave

\footnotetext{
${ }^{28}$ And from a lower initial level.

${ }^{29}$ Argentina, Australia, Belgium, Brazil, Canada, Denmark, Finland, France, Germany, Italy, Japan, Norway, Portugal, Sweden, Switzerland, the UK and the US. The 1925 and 2004 GDP data used to weight individual countries' money supply series are taken from Maddison (2009). For the interwar period, the sources are given in the data appendix: the data are for M1 for all countries bar Denmark, Finland and Sweden, for which we only have M2. The modern data are for M1, and the source is the IMF's International Financial Statistics and the OECD's Monthly Economic Indicators. The data are expressed in index form, taking 1925=100 and $2004=100$. ${ }^{30}$ The current data are taken from the IMF's World Economic Outlook Update of October 2009, and include forecasts for 2009 through 2014 from http://www.imf.org/external/pubs/ft/weo/2009/02/c1/fig1_ 7.csv. As before, the interwar data are GDP-weighted averages of individual country data, with the data sources listed in the appendix. We have data for 21 countries: the same 17 as before, plus Bulgaria, Hungary, India and the Netherlands. The interwar data include both ordinary and extraordinary budgets and closed accounts wherever possible. However, the League of Nations (1934, Chapter VII) warns that while it has attempted to capture special accounts (such as those of railways, the post office and other government monopolies), supplementary budgets and the like, this is problematic. These problems will be familiar to fiscal policy specialists in the current period, but in the 1930s they were if anything more severe.
} 
central banks the option of responding aggressively. ${ }^{31}$ There are exceptions, to be sure. A first category consists of countries with currency boards (Hong Kong and Bulgaria, for example). A second concerns those countries with substantial foreign-currency-denominated liabilities for which substantial depreciation would have been destabilizing (Hungary, South Korea). A third concerns countries pegging their currencies to other currencies, notably the euro via the so-called “ERM II” (Denmark and the Baltic states). In some cases these countries’ exchange rate commitments have led to perverse policy responses, or at the least tied their hands in dealing with the current crisis. An example is Denmark, which raised its interest rates twice in October 2008, a time of severe distress in international financial markets. ${ }^{32}$ The broader picture, however, is one of a world economy in which monetary authorities were unfettered by exchange rate obligations and consequently free to combat the crisis using both traditional and non-traditional methods.

In the Great Depression countries remaining on the gold standard were unable to engage in expansionary monetary policy. They were also reluctant to apply fiscal stimulus, since this could lead to a drain of reserves by attracting imports - although, as we show below, they too saw their budget balances move into deficit due to declining revenues. This suggests distinguishing the gold bloc (Belgium, France, and Switzerland); the sterling area (Australia, Canada, Denmark, Finland, Norway, Portugal, Sweden and the UK); other depreciators (Argentina, Brazil, Japan and Spain); the USA, which moved relatively late from being on the gold standard to depreciation in 1933; the exchange control countries (here represented by Germany and Austria); and Italy (which was in name a member of the gold bloc but which from early on imposed foreign exchange controls and bilateral clearing).

\footnotetext{
${ }^{31}$ Here we are treating the euro area as the relevant economic unit rather than its individual constituent states say Ireland.

${ }^{32}$ However, it has since lowered them to $1.15 \%$.
} 
Figure 12, based on the same interwar money supply data as Figure 10, plots a GDPweighted index for each group with the 1929 level set equal to $100 .^{33}$ There is a very sharp rise in gold bloc money supplies between 1925 and 1931, driven by an undervalued French currency attracting gold supplies to that country, followed by an equally sharp decline through 1935. Sterling area money supplies declined gently until 1932, when they started to expand, while other depreciators (many of which were commodity exporters and capital importers) saw their money supplies contract between 1928 and 1931 (as commodity prices and capital inflows both fell off) and then recover sharply. The money supply declined sharply in the US between 1929 and 1933 (the point made famous by Friedman and Schwartz), after which it recovered equally sharply. In the exchange control countries, many of which experienced financial crises, money supplies continued falling for several years, after which governments used their room for manoeuvre to reverse the trend.

Figure 13 show the same breakdown for fiscal policy. ${ }^{34}$ All groups were running deficits by 1932, although relatively small ones by the standards of today. In 1934, the last year for which data are available for the exchange control countries, the deficits were highest in the 'gold and exchange controls' bloc, the US, the gold bloc, and the exchange control countries, in that order. The relatively large deficits of the gold bloc and 'gold and exchange controls' countries, and the sharp reversal in US fiscal policy in 1937 and 1938, stand out. The other depreciators and sterling bloc countries, in contrast, ran fairly balanced budgets.

\section{The Impact of Policy in the 1930s}

Eventually, countries started exiting the Depression, with the timing of recovery depending on how long they clung to the gold standard. In some cases recovery was

\footnotetext{
33 Austria and Spain were not included in the earlier graph since data for these countries are only available through 1936 and 1935 respectively.

${ }^{34}$ Using the same measure as in Figure 11. Bulgaria and Hungary are now added to the exchange control group. Czechoslovakia is added to the 'gold and exchange controls' group, along with Italy. Austrian data are only available through 1936, which is why the series ends in that year. Similarly the Spanish data, and hence the 'other depreciators' series, both end in 1935. India is included with the sterling bloc.
} 
impressive: the US grew by 8 per cent per annum between 1933 and 1937 (Romer 1992, p. 757). The question, for it and other countries, is: to what extent did this represent a 'rubber band' effect, with the strength of the rebound reflecting the scale of the previous collapse, and to what extent did it reflect expansionary monetary and fiscal policies?

Romer's answer for the US is unequivocal: "Monetary developments were a crucial source of the recovery of the U.S. economy from the Great Depression. Fiscal policy, in contrast, contributed almost nothing to the recovery before 1942” (p. 781). The positive finding for monetary policy reflects abandonment of the gold standard and the large gold inflow after 1933, while the negative finding for fiscal policy reflects the very small size of deficits.

Ritschl (2005) similarly finds that fiscal deficits were too small to have made an economically consequential difference in Nazi Germany. Not even in Sweden, a country where Keynesian ideas were circulating avant la lettre, were fiscal deficits big enough to make a significant difference (Schön 2007). Appendix 2 shows that what was true for the United States and Germany was true for other countries: in most cases budget deficits were moderate, and even remained below the per cent threshold that has become familiar to European readers since the 1990s. The decade that saw the publication of The General Theory did not see the widespread adoption of Keynesian pump-priming measures.

But had such measures been adopted, would they have been effective? And did the changes in monetary stance when countries abandoned the gold standard, documented in Section 3 above, have a significant impact on output, or were their effects neutralized by the liquidity trap and dysfunctional financial systems? It is widely argued that monetary policy was ineffective in the 1930s owing to a near-zero interest rate environment in which banks had no incentive to lend out the additional resources they could obtain as a result of the easy credit made available by their central banks. By implication it has been argued that monetary 
policy was likely to be ineffective in 2008-9, again owing to the existence of a deflationary, near-zero interest rate environment. It is also argued that fiscal policy is unlikely to boost output in the deflationary, near-zero interest rate environment of 2008-9 because it didn't work in the 1930s. The IMF (2009, p.104) suggests that monetary policies become less effective at times of financial crisis, whereas fiscal policies become more so. Again, the 1930s would seem to be the ultimate testing ground of these generalizations.

We therefore estimate the impact of fiscal and monetary policy during the interwar period using panel data for 27 countries between 1925 and $1939 .{ }^{35}$ We do so in several ways, using panel VAR techniques, panel regressions, and instrumental variables.

\section{Panel VAR estimates}

We start by estimating government expenditure multipliers with VAR models, relying on a recursive ordering to identify shocks. Since the assumptions regarding ordering are central to the identification strategy, given the absence of more structure, it is important to acknowledge that there is less than complete consensus on the appropriate ordering when total government spending is the fiscal variable whose output effects we wish to consider. The common assumption is that government spending does not respond to output in the current period: contemporaneous government spending is effectively "exogenous” with respect to output. If however those responsible for government spending decisions formulate them with future output movements in mind - since they worry about the depth of the impending recession - then this ordering will be problematic. It can be argued that during the Great Depression, before the triumph of Keynesianism and when there was little recognition of how spending decisions might be used to offset changes, both contemporaneous and

\footnotetext{
${ }^{35}$ Australia, Bulgaria, Canada, Chile, Colombia, Denmark, Greece, India, Japan, Netherlands, New Zealand, Norway, Portugal, Spain, Czechoslovakia, Argentina, Austria, Belgium, Finland, France, Germany, Hungary, Italy, Sweden, Switzerland, United Kingdom and United States.
} 
future, in output and employment, this assumption is defensible. But, regardless of period, the assumption is strong.

Taking this into account, we use defence spending as our fiscal policy variable. This is the strategy adopted by Blanchard and Perotti (2002) to study U.S. fiscal multipliers since the $1950 \mathrm{~s}^{36}$ Their defence-spending multipliers range from 0.87 to 2.5 in a specification including a deterministic trend, and from 0.82 to 1.91 in the model with a stochastic trend. In a recent paper, Barro and Redlick (2009) also study the impact of defence spending on output with a single equation model using annual U.S. data for the $1912-2006$ period. ${ }^{37}$ Their findings are that defence-spending multipliers range between 0.59 and 0.77 , depending on the sub-period. In similar fashion Hall (2009) uses changes in U.S. defence spending to estimate fiscal multipliers for several sub-periods during 1930-2008. These range from 0.36 to 0.55 .

When assessing the impact of monetary policy, Romer (1992) looks at trends in M1. In statistical work not reported in this paper, we have found that there is a strong relationship between M1 and GDP internationally during this period. ${ }^{38}$ However, M1 is determined not just by the monetary base, the variable under the control of the central bank, but by the money multiplier, which is endogenous. ${ }^{39}$ For this reason, we have chosen to use the central bank discount rate as our measure of monetary policy.

Given our global perspective it would be problematic to rely on multipliers derived from the experience of one country (as do Romer, Blanchard-Perotti, Barro-Redlick and Hall). Instead we estimate these using our panel of 27 countries and data for the period 1925-

\footnotetext{
${ }^{36}$ Below we report some sensitivity analysis substituting total government spending for defence expenditures.

${ }^{37}$ Since their focus is on U.S. military build-ups during wars, they include as explanatory variables changes in defence spending and this variable interacted with a war dummy.

${ }^{38}$ Specifically, in impulse-response functions of estimated VARs analogous to those reported immediately below, but with $\mathrm{M} 1$ in place of the central bank discount rate, there is a strong, statistically significant positive effect of an M1 shock on GDP.

${ }^{39}$ So it is not surprising that there is such a strong correlation between M1 and GDP in the data.
} 
1939. We study the impact of defence spending and monetary shocks by estimating the reduced form of the following structural model:

$$
\begin{aligned}
& A_{0} Z_{i, t}=A(L) Z_{i, t-1}+C X_{i, t}+e_{i, t}^{40} \\
& Z_{i, t}=\left\lfloor\begin{array}{llll}
G_{i, t} & Y_{i, t} & T_{i, t} & R_{i, t}
\end{array}\right\rfloor \text { is a vector containing the endogenous variables of the }
\end{aligned}
$$

system. $G$ stands for defence spending, $Y$ is GDP, $T$ is government revenues and $R$ is the central bank discount rate. ${ }^{41} A_{0}$ is a nonsingular matrix that captures the contemporaneous relationships between the endogenous variables and is given by:

$$
A_{0}=\left[\begin{array}{cccc}
1 & -\alpha^{Y G} & -\alpha^{T G} & -\alpha^{R G} \\
-\alpha^{G Y} & 1 & -\alpha^{T Y} & -\alpha^{R Y} \\
-\alpha^{G T} & -\alpha^{Y T} & 1 & -\alpha^{R T} \\
-\alpha^{G R} & -\alpha^{Y R} & -\alpha^{T R} & 1
\end{array}\right] .
$$

$A(L)$ is the matrix polynomial in the lag operator $L$ that captures the relationships between the endogenous variables and their lags. Following the Akaike Information and Schwarz Bayesian Information Criteria, we include one lag for each endogenous variable. One lag turns out to suffice to eliminate first-order residual autocorrelation. We control for country-specific heterogeneity by including country fixed effects and linear trends. The latter are also included to induce stationarity. ${ }^{42}$ We add year dummies to control for cross-country residual autocorrelation. The vector $X_{i, t}$ contains these, and matrix C the associated

${ }^{40}$ The reduced-form version is given by $Z_{i, t}=B(L) Z_{i, t-1}+D X_{i, t}+u_{i, t}$, where $B(L)=A_{0}^{-1} A(L)$, $D=A_{0}^{-1} C$ and $u_{i, t}=A_{0}^{-1} e_{i, t}$.

${ }^{41}$ Fiscal variables are deflated using GDP deflators. To ensure cross-country homogeneity we construct index numbers for defence expenditure, revenues and GDP. The model is estimated using the log level of these variables.

${ }^{42}$ Stationarity was also checked using two Fisher-type tests (based on the augmented Dickey-Fuller and the Phillips-Perron tests). We find that revenue and the central bank discount rates are stationary. In contrast, we cannot reject the null hypothesis of a unit root in defence spending or GDP. The caveat is that the power of these tests may be undermined the short time span (15 years at most). However, since we de-mean and de-trend each variable included in the VAR, the system is less likely to be nonstationary. 
coefficients. Finally, $e_{i, t}$ includes the mutually uncorrelated structural shocks to each endogenous variable.

As noted above, we identify shocks using a recursive ordering. That is, we assume that some variables do not react to shocks to other variables contemporaneously. We impose the following zero restrictions on $A_{0}$ :

$$
-\alpha^{Y G}=-\alpha^{T G}=-\alpha^{R G}=-\alpha^{T Y}=-\alpha^{R Y}=-\alpha^{R T}=0 .
$$

These imply that defence spending does not react contemporaneously to shocks to $Y$, $T$ or $R$, that $Y$ does not react to shocks to $T$ and $R$, and that $T$ does not react to shocks to $R$.

As noted above, the assumption of $G$ not responding contemporaneously to output shocks is consistent with both logic and evidence suggesting that within-year feedbacks from GDP to government spending are not significant. ${ }^{43}$ Importantly, this assumption is more defensible when the government-spending variable is defence spending rather than total spending, since defence spending responds to things other than changes in GDP. In the 1930s it was driven above all by Hitler’s rearmament programmes and other nations’ efforts to match the Nazis in this sphere, and by one-off events like Italy’s war in Abyssinia.

We place government revenues in the third position since that variable responds to the level of economic activity through the operation of the tax system. ${ }^{44} T$ is ordered after $G$ on the grounds that government expenditure is planed in a budget that is presented before the

\footnotetext{
${ }^{43}$ Beetsma et al (2006) estimate a panel VAR for Finland, France, Germany, Italy, the Netherlands, Sweden and the UK using non-interpolated quarterly data and assuming that government spending does not react to output shocks within a quarter (as in Perotti 2005). With this model, they later construct estimates of the government spending response to output shocks at annual frequency. Their findings are that it does not react to output shocks within a year. Moreover, several other studies also assume that government consumption has a contemporaneous effect on output (Blanchard and Perotti 2002, Perotti 2005, Monacelli and Perotti 2006, Galí et al 2007, Ravn et al 2007 and Beetsma et al 2008).

${ }^{44}$ In contrast, Beetsma et al (2006), Blanchard and Perotti (2002) and Perotti (2005) order revenues after government expenditure and before output. However, their measure of revenues is cyclically adjusted net taxes. Our measure is not cyclically adjusted. Thus, it will respond to output shocks within the same year. As a test, we also estimated the model placing revenues before output and find that the output response to government expenditure shocks is not altered.
} 
start of the fiscal year (Beetma el at 2006). In our context it also makes sense to think that the authorities adjust revenues, in part, in response to changes in the need for defence expenditures. Finally, as in Christiano et al (2005), we assume that monetary policy shocks do not affect GDP contemporaneously. ${ }^{45}$ That is, we place the central bank discount rate in the last position, but as noted below we check the robustness of our results to changing this assumption. In sum, we use the following Cholesky ordering: $G, Y, T, R$.

Alternative identification strategies are the `narrative’ and `sign restriction’ approaches. The former, used by Ramey and Shapiro (1998) and Ramey (2009), studies the effect of shocks to a dummy variable that identifies years with large and unexpected changes in fiscal policy. The narrative approach obviously relies heavy on the judgment of the investigator. The two afore-mentioned papers concentrate on the U.S. and take sudden military build-ups as unexpected fiscal shocks. This strategy, also implemented for tax shocks in Romer and Romer (2009), would be difficult to employ in our multi-country panel, since we do not have comparable narrative evidence for all of our countries. ${ }^{46}$

The sign-restriction approach uses the sign of the cross-correlation function in response to shocks to assign a structural interpretation to the orthogonal innovations. ${ }^{47}$ This requires taking a strong stand on the predicted sign impact of shocks, which would not be appropriate in the current context. In addition, this approach requires a strong stand on how long these restrictions continue to hold. Papers using this identification strategy typically use monthly or quarterly data and assume that these constraints hold only for a short period, which makes the approach not suitable for our panel of annual data. They also include more endogenous variables than we have available, since they are imposing sign constraints in the

\footnotetext{
45 Admittedly our assumption is stronger since we use annual data.

46 They use narrative evidence based on congressional reports and other sources to assess significant pieces of tax legislation from 1945 to 2007. They estimate each tax change by the size and timing of its intended effect upon federal tax revenues. This approach avoids the problem of endogeneity because it is based on planned changes in federal tax revenues prior to the legislative process.

${ }^{47}$ See Canova and Denicoló (2002) and Uhlig (2005) for monetary shocks, or Canova and Pappa (2007) and Mountford and Uhlig (2009) for fiscal shocks.
} 
context of models incorporating a great deal more economic structure than our own reduced form exercise.

Results

Since real defence spending (our government expenditure proxy) and real GDP are in log levels, our model yields the elasticity of output with respect to defence spending. To convert this into a defence-spending multiplier we divide it by the ratio of government defence spending to GDP, on the (baseline) assumption that this is the same across countries (the baseline ratio is 2.4 percent). ${ }^{48}$ The defence spending shock is equivalent to one percent of GDP. For shocks to the central bank discount rate, we do not use a scaling factor. The assumed discount rate shock is a one percentage point change.

Figure 14 presents the responses to a shock to defence spending. It shows that innovations in this variable are expansionary. This shock explains, on average, 6 per cent of the forecast error variance of the GDP equation in a five-year horizon. Defence-spending multipliers are 2.5 on impact and 1.2 after the initial year. These are at the upper end of the range of multipliers estimated using modern U.S. public spending data. ${ }^{49}$ The absence of a fiscal policy effect on output during the 1930s does not reflect the absence of a positive fiscal policy multiplier, it would appear. Note that this is also the conclusion of Romer (1992) in her calibration exercise for the United States in the 1930s.

Figure 15 presents the responses to a one unit shock to the central bank discount rate. The percentage of forecast error variance in the GDP equation attributable to this shock is small. On average this variable explains only one per cent of the GDP forecast error variance

\footnotetext{
48 To construct it, we compute the cross-country average of total defence spending divided by GDP in the 19251939 period.

${ }^{49}$ They are considerably larger than the U.S. defence-spending multipliers reported by Hall (2009).
} 
in a five-year horizon. While a positive shock to the discount rate is associated with a decline in GDP, the effect is not statistically significant.

\section{Robustness checks ${ }^{50}$}

As a first robustness check, we estimated a version of this model using total government spending. This yields fiscal multipliers of 0.43 on impact and 0.13 after one year, which are consistent with those estimated for the U.S. in the recent period (which range between 0.37 and $0.9 .^{51}$ As noted above, however, there are grounds for doubting whether this specification is adequately identified, which is why we prefer looking at the impact of defence expenditure, which is more obviously exogenous.

A further robustness check aims at tackling the potential bias in the coefficients owing to the inclusion of country fixed-effects in a short dynamic panel. Country-specific intercepts may induce a correlation between the residuals and the future value of the regressors. As Nickell (1981) and Arellano (2003) point out, these are more likely to emerge in short panels with a large cross-section dimension. We therefore re-estimated the model excluding the country fixed-effects. ${ }^{52}$ The qualitative results are not altered. The main difference is that the GDP response to a fiscal shock is more persistent.

Another check is to control for bias due to the omission of other spending measures that may be correlated with defence. To check this, we added an endogenous variable measuring non-defence spending. The GDP response to a defence shock does not change. Nor does it change when we exclude tax revenues from the VAR.

\footnotetext{
${ }^{50}$ Results available on request.

${ }^{51}$ Again, see Blanchard and Perotti (2002), Galí et al (2007), Perotti (2007) and Ramey (2008). To compute the multipliers we scale the responses with the total expenditure over GDP ratio. This is equal to 14 percent.

${ }^{52}$ Given the length of our dataset, the alternative of implementing GMM methods using many lags of the endogenous variables as instruments would have a high cost in terms of degrees of freedom.
} 
Following other recent studies estimating fiscal multipliers using annual data and panel VARs (e.g. Beetsma et al 2006, 2008), we also tried including two lags of each endogenous variable. Again the qualitative results did not change. These are also robust to the exclusion of the year dummies. Moreover, they do not change when we exclude the linear trends, or replace these by quadratic trends.

Another check is to alter the Cholesky ordering. Since the assumption of monetary policy not having a within year effect on GDP is strong, we also used an alternative ordering in which we estimated the impulse-response functions placing $\mathrm{R}$ in the first position. Figure 16 shows that when the ordering is altered in this way a 100 basis point increase in the central bank discount rate produces a relatively small but now statistically significant fall in output.

Finally, we estimated the models in differences (excluding the country fixed effects, linear trends and year dummies). Our results do not change for the defence shocks (Figure 17). But, shocks to the central bank discount rate now clearly contract output (Figure 18). This result emerges in both the baseline Cholesky ordering (when $\mathrm{R}$ is ordered in the last position) and in the alternative ordering (when $\mathrm{R}$ is ordered first).

Panel VAR estimates: an alternative approach

As an alternative strategy, we study the dynamic effect of defence shocks by estimating the reduced form of the following structural model

$$
A_{0} Z_{i, t}=A(L) Z_{i, t-1}+C X_{i, t}+D G_{i, t}{ }^{\text {defence }}+e_{i, t},
$$

where $Z_{i, t}=\left\lfloor\begin{array}{llll}G_{i, t} \text { total-defence } & Y_{i, t} & T_{i, t} & R_{i, t}\end{array}\right\rfloor$. As in the previous robustness check, $G_{i, t}{ }^{\text {total-defence }}$ measures non-defence spending. $G_{i, t}{ }^{\text {defence }}$ are defence spending and $D$ is a vector with the associated coefficients. 
In contrast to the previous specifications, we include defence as an exogenous variable in each equation of the system. Therefore, the identification of a defence shock does not rely on a recursive ordering (we do not impose any restriction on $A_{0}$ ).

This strategy is similar to the approach in Ramey and Shapiro (1998), Burnside et al (2004) and Perotti (2007) mentioned above. ${ }^{53}$ In these studies, the shocked variable is a dummy variable that identifies abnormal fiscal events like military buildups. However, we use a continuous variable (defence spending) rather than a binary variable.

Figure 19 shows the responses of all the endogenous variables to a transitory shock to defence spending. As before, we scale the responses to get the associated fiscal multiplier. In line with the previous findings, defence expenditure is expansionary. It produces a statistically significant impact multiplier of 2.1. Moreover, this positive effect is present in years one, two and three (the associated multipliers are $0.9,0.4$ and 0.2 , respectively).

\section{Estimates}

Another way of estimating the impact of government policies is to run panel models using IV techniques. This provides further sensitivity analysis in the sense that the IV approach rests on a somewhat different identification strategy (instruments rather than lags). IV methods also allow us to look directly at the magnitude of the output response to changes in overall government spending, the policy variable we are really interested in. ${ }^{54}$

We use data for the period 1925-39 and the same 27 countries to estimate:

$$
d Y_{i . t}=\alpha_{i}+\lambda_{t}+\beta_{m} R_{i, t}+\beta_{f} d G_{i, t}+\varepsilon_{i, t}
$$

\footnotetext{
${ }^{53}$ While Ramey and Shapiro (1998) implement this strategy in a univariate model, Burnside et al (2004) and Perotti (2007) do it in a VAR context.

${ }^{54}$ By instrumenting the latter.
} 
where $d Y_{i, t}$ is the growth of real GDP, $R_{i, t}$ is the central bank discount rate, and $d G_{i, t}$ is the growth in total real government spending. These variables are defined as in the previous section ( $d Y_{i, t}$ and $d G_{i, t}$ are differences of the natural logarithms of index numbers). The $\alpha_{i}$ are country fixed effects, i.e., unobservable and time-invariant characteristics of the countries in the sample. ${ }^{55}$ Similarly, $\lambda_{t}$ captures year fixed effects.

Estimating this model by OLS is problematic, of course, owing to potential endogeneity: government policy affects GDP, but GDP also affects the macroeconomic policies that governments implement. We therefore instrument for total expenditures and the central bank discount rate. The first instrument we use is defence spending. This variable is strongly related to overall public expenditures and to the government surplus, while during this period it was determined mostly by purely political factors, rather than economic factors, as noted in the preceding section. We use a dummy variable for whether or not a country was on the gold standard as our second instrument. As we saw in Section 3, adherence to the gold standard was a powerful determinant of and constraint on monetary policy. Countries abandoning gold were quicker to cut interest rates in response to the slump. And, as argued in Eichengreen and Sachs (1985) and subsequent literature, the decision of whether to maintain or abandon gold starting in the late 1920s was heavily influenced by prior experience: countries that had suffered high inflation in the first half of the decade (before our sample period begins) were more inclined to adhere strictly to the gold standard once the Depression struck.

\section{Results}

While we consider the IV results to be definitive, we report the OLS results for the sake of completeness and comparison (Table 1). Moreover, we estimate both sets of

\footnotetext{
${ }^{55}$ In controlling for these we are ensuring that our estimates are not affected by idiosyncratic country features such as political ideology, the effectiveness of government and institutions, etc.
} 
regressions with and without year dummies. ${ }^{56}$ We estimate all equations using both fixed effects and random effects. Hausman tests indicate that we cannot reject the random effects estimator, except in the case of the OLS regression excluding time dummies.

Looking across Table 1, we find that government expenditure has a positive and significant impact on output in seven out of eight cases. The exception is the fixed effects IV regression with time dummies; even in that case, however, the coefficient is positive and large. The loss of statistical significance there is due to larger standard errors rather than a much smaller coefficient. Note that the estimated impact of fiscal policy is larger in the IV than OLS regressions. This is consistent with the results produced by the VAR models, where we found much larger fiscal multipliers when we estimated these with (exogenous) defence spending, than when we did so with (potentially endogenous) total government expenditure. To give one example, the coefficient of 0.195 in the fifth column implies a multiplier between 1.1 and 2.2, and a multiplier of 1.6 when evaluated at the median values of the ratio of GDP to expenditure, and the growth rates of expenditure and GDP. ${ }^{57}$

In estimating the impact of monetary policy, it turns out to matter whether or not we control for year fixed effects. When these are not included, the estimated impact of the central bank discount rate on GDP is both negative and statistically significant at conventional levels in three out of four cases. When the vector of year dummies is added, however, the monetary-policy variable loses significance in all regressions, although the coefficient remains negative.

Again the bulk of this evidence inclines toward the view that policy could have made a significant difference in the 1930s. But we provide the entire set of empirical estimates to enable the reader to make her own judgment regarding the robustness of the results.

\footnotetext{
${ }^{56} \mathrm{By}$ including these, we are making sure that events that impacted all countries in a given year (i.e. common fluctuations) are not affecting our estimates.

57 Details of the calculations are available on request.
} 
Panel OLS estimates: an alternative approach

Finally, we estimated the impact of monetary and fiscal policies by regressing output on fiscal shocks and the central bank discount rate. To recover the government spending shocks, we assumed that the fiscal spending variable follows an autoregressive process. We estimated this process and took the residuals associated with it to be the fiscal shocks. ${ }^{58}$

Table 2 presents panel estimates taking output as the dependent variable and the aforementioned fiscal shocks, the central bank discount rate, and the lagged value of output as explanatory variables. ${ }^{59}$ To control for country-specific heterogeneity we include country fixed effects. Moreover, we estimate these with and without year dummies to control for global factors.

Our findings are consistent with the previous results. We find that government spending shocks are expansionary, with multipliers ranging from 0.35 to 0.39 . An increase in the central bank discount rate contracts output.

Alternatively, we estimated this specification for defence shocks, where the defence shocks are obtained in a similar manner. This model yields the same qualitative results. However, since the average ratio of defence spending to output is much smaller, the associated multipliers are larger.

\section{Conclusions}

We have asked two questions about the 1930s. First, what policies were actually used to get countries out of the Depression? Second, did they make a difference? In the early stages of the current crisis, which resembled the 1930s for the existence of financial distress,

\footnotetext{
${ }^{58}$ A similar strategy is carried out by Fatás and Mihov (2003) in order to eliminate automatic fiscal responses to the business cycle and get and indicator of discretionary fiscal policy. However, their fiscal policy shocks are obtained by regressing government primary balances on growth, inflation and a short-run interest rate.

${ }^{59}$ These results are not affected if we include two lags of GDP as explanatory variables.
} 
economic slack, and worries about deflation, there was scepticism that monetary and fiscal stimulus would be effective in setting the stage for recovery and growth. Monetary policy, it has been argued, is ineffective when the banking system is in distress and interest rates approach zero. Fiscal policy is ineffective when the need is to reduce levels of indebtedness, not raise them, and when much previous output and employment in the declining sectors is unsustainable; it cannot simply be replaced by replacing demand.

Our results push back against this scepticism. They suggest that fiscal policy made little difference during the 1930s because it was not deployed on the requisite scale, not because it was ineffective. They suggest a positive impact of government expenditure on GDP during the interwar period, with substantial fiscal multipliers: for example, the first set of VAR exercises suggested that these were 2.5 on impact and 1.2 after one year. Where significant fiscal stimulus was provided, output and employment responded accordingly. Individual country experience with large fiscal stimulus was rare in this period, but where it occurred the evidence points in the same direction. One of the biggest fiscal stimuli in this sample occurred in Mussolini’s Italy during 1936-7, as a result of the war in Ethiopia. Italy ran a deficit in excess of 10 per cent of GDP in 1936 and 1937. Italian GDP grew by 6.8 per cent in 1937, by a marginal amount in 1938, and by $7.3 \%$ in 1939 . According to Toniolo (1976), the Italian economy moved to full employment during this period. In France, the budget deficit increased substantially beginning in 1935, and GDP grew by 5.8 per cent in 1936. The deficit exploded in 1939, during which year the economy grew by no less than 7.2 per cent. These examples remind us, of course, that the real Keynesian stimulus, when it came, would be associated with military expenditure during World War II, producing very rapid growth in countries like the United States. In our view, peacetime stimulus packages, which could have halted the rise in unemployment that ultimately led to the election of Adolf Hitler (according to King et al. 2008), would have been preferable to the stimulus of war. 
We have also provided some evidence that monetary policy was effective in the 1930s. In the IV regressions without time dummies, in the panel regressions in Table 2, and in the VARs in differences, we found that central bank discount policy was effective in boosting GDP. ${ }^{60}$ These results are less robust than those for fiscal policy, but again we think that the implications are clear. To the extent that the world economy is again experiencing a significant demand shortfall and is at risk of deflation, both monetary and fiscal stimuli are appropriate. In current conditions there is good reason to expect them to be effective.

The IMF estimated in October that world output would contract by $1.1 \%$ in 2009. In its October World Economic Outlook it estimated that the G-20 would implement crisisrelated fiscal stimulus equivalent to 2 per cent of GDP during 2009. It also estimated that worldwide government fiscal balances would deteriorate by the equivalent of 4.6 per cent of world GDP (comparing 2009 with 2008). OECD (2009b) has estimated that OECD governments are embarking on an expenditure stimulus equivalent to 1.7 per cent of GDP during 2008-10, and on a total fiscal stimulus of 3.4 per cent over the same period. Fiscal stimuli of this size, and fiscal multipliers of the size we have estimated in this paper, together suggest that the world economy would have contracted by a great deal more than 1.1 per cent in 2009 if we had seen the same passive policy response that characterised the years after 1929.

It remains unclear exactly how big the realised fiscal stimulus has been in 2009. Pending firmer data on the size of the fiscal shock, a simple thought experiment will have to suffice. Imagine that discretionary fiscal policy led to a positive government expenditure shock of 1 per cent of world GDP in 2009. A fiscal stimulus of that size would increase world GDP (on impact, i.e. in 2009) by between 0.35 to 2.5 per cent based on our estimated multipliers. This in turn implies that without such a stimulus, world GDP in 2009 would be

\footnotetext{
${ }^{60}$ The effect was also statistically significant in the VARs in levels, when R was first in the Cholesky ordering.
} 
contracting not by 1.1 per cent, but by 1.4 to 3.5 per cent. This compares with a world GDP contraction in 1930 of 2.9 per cent. Factoring into the equation the role of expansionary monetary policy would make the role of policy even bigger, and the counterfactual 'no policy response' fall in GDP even larger. Factoring into the equation the role of government in preventing banking collapses during this crisis would make the role of policy appear larger still.

A final implication of these conclusions is that it would be foolhardy to withdraw policy support until it is clear that retrenchment can take place without killing off any incipient economic recovery. Repeating the mistakes of the 1920s is no excuse for repeating those of the 1930s. 


\section{References}

Arellano, M. 2003. Panel Data Econometrics. Oxford: Oxford University Press.

Amiti, M. and D.E. Weinstein. 2009. “Exports and Financial Shocks.” Mimeo.

Auboin, M. 2009a. "The Challenges of Trade Financing.”

http://voxeu.org/index.php?q=node/2905

Auboin, M. 2009b. “Trade Finance: G20 and Follow-Up.” http://www.voxeu.org/index.php?q=node/3635

Bairoch, P. 1982. “International Industrialization Levels from 1750 to 1980.” Journal of Eurpean Economic History 11: 269-331.

Barro, R.J. and C.J. Redlick. 2009. "Macroeconomic Effects from Government Purchases and Taxes”. NBER Working Paper No. 15369.

Beetsma, R., M. Giuliodori and F. Klaassen. 2006. "Trade Spill-Overs of Fiscal Policy in the European Union: a Panel Analysis.” Economic Policy 21(48): 639-687.

Beetsma, R., M. Giuliodori and F. Klaassen. 2008. "The Effects of Public Spending Shocks on Trade Balances and Budget Deficits in European Union.” Journal of the European Economic Association 6: 414 - 423.

Bernanke, B.S. 2000. Essays on the Great Depression. Princeton: Princeton University Press.

Bernanke, B.S. and I. Mihov. 2000. "Deflation and Monetary Contraction in the Great Depression: An Analysis by Simple Ratios.” In Bernanke (2000).

Blanchard, O. and R. Perotti. 2002. "An Empirical Characterization of the Dynamic Effects of Changes in Government Spending and Taxes on Output.” Quarterly Journal of Economics 117: 1329 - 1368.

Burnside, C., M. Eichenbaum and J.D.M. Fisher. 2004. "Fiscal Shocks and their Consequences.” Journal of Economic Theory 115: 89-117.

Buyst, E. and P. Franaszek. 2009. “Sectoral Developments, 1914-1945,” in S. Broadberry and K.H. O’Rourke (eds.), Cambridge Economic History of Modern Europe, Volume 2, Cambridge: Cambridge University Press.

Canova, F. and G. De Nicoló. 2002. "Monetary Disturbances Matter for Business Fluctuations in the G-7. Journal of Monetary Economics 49: 1131-1159.

Canova, F. and E. Pappa. 2007. "Price Differentials in Monetary Unions: The Role of Fiscal Shocks.” Economic Journal 117: 713-737.

Christiano, L., M. Eichenbaum and C.L. Evans. 2005. "Nominal Rigidities and the Dynamic Effects of a Shock to Monetary Policy. Journal of Political Economy 113: 1-45. 
Edelberg, W., M. Eichenbaum and J.D.M. Fisher. 1999. "Understanding the Effects of a Shock to Government Purchases.” Review of Economic Dynamics 2:166-206.

Eggertsson, Gauti (2008), “Great Expectations and the End of the Depression,” American Economic Review 98: 1476-1516.

Eichengreen, B. 1992. Golden Fetters: The Gold Standard and the Great Depression 19191939. Oxford: Oxford University Press.

Eichengreen, B. and J. Sachs (1985), “Exchange Rates and Recovery in the 1930s.” Journal of Economic History 44: 925-946.

Fatás A. and I. Mihov 2003. “On Constraining Fiscal Policy Discretion in EMU.” Oxford Review of Economic Policy 19(1):112-131.

Findlay, R. and K.H. O’Rourke. 2007. Power and Plenty: Trade, War, and the World Economy in the Second Millennium. Princeton: Princeton University Press.

Francois, J. and J. Woerz. 2009. “The Big Drop: Trade and the Great Recession.” http://www.voxeu.com/index.php?q=node/3527

Freund, C. 2009. "Demystifying the Collapse in Trade." http://www.voxeu.org/index.php?q=node/3731

Galí, J., J.D. López-Salido, and J. Vallés. "Understanding the Effects of Government Spending on Consumption.” Journal of the European Economic Association 5: 227-270.

Hall, R.A. 2009. "By how much does GDP rise if the government buys more output?” Mimeo, Stanford University.

Helbling, T. 2009. "How Similar is the Current Crisis to the Great Depression?" http://www.voxeu.org/index.php?q=node/3514

International Monetary Fund (2009), World Economic Outlook, Washington, D.C.: IMF (April).

King, G., O. Rosen, M. Tanner and A.F. Wagner. 2008. "Ordinary Economic Voting Behavior in the Extraordinary Election of Adolf Hitler.” Journal of Economic History 68: 951-996.”

League of Nations. 1934. Public Finances. Geneva: League of Nations.

League of Nations. 1939. World Production and Prices 1938/39. Geneva: League of Nations. League of Nations. 1945. Industrialization and Foreign Trade. Geneva: League of Nations. Maddison, A. 2009. Statistics on World Population, GDP and Per Capita GDP, 1-2006 AD (March 2009 update). http://www.ggdc.net/maddison/

Monacelli, T. and R. Perotti. 2006. "Fiscal Policy, the Trade Balance and the Real Exchange Rate: Implications for International Risk Sharing.” Mimeo , Universitá Bocconi. 
Mountford, A. and H. Uhlig. 2009. “What are the Effects of Fiscal Policy Shocks?” Journal of Applied Econometrics, forthcoming.

Nickell, S. J. 1981. Biases in Dynamic Models with Fixed Effects. Econometrica 49: 141726.

OECD 2009a. OECD in Figures 2008. Paris: OECD.

OECD 2009b. "Fiscal packages across OECD countries: Overview and country details", OECD Economic Department, March 2009.

Perotti, R. 2005. "Estimating the Effects of Fiscal Policy in OECD Countries.” CEPR Discussion Paper No. 4842.

Perotti, R. 2007. "In Search of the Transmission Mechanism of Fiscal Policy.” NBER Working Paper No. 13143.

Ramey V.A. 2009. “Identifying Government Spending Shocks: It’s All in the Timing.” Mimeo, University of California, San Diego.

Ramey, V.A. and M.D. Shapiro. 1998. "Costly Capital Reallocation and the Effects of Government Spending.” Carnegie-Rochester Conference Series on Public Policy 48:145-194.

Ravn, M., S. Schmitt-Grohe and M. Uribe. 2007. "Explaining the Effects of Government Spending Shocks on Consumption and Real Exchange Rate. NBER Working Paper No. 13328.

Ritschl, A. 2005. “The Nazi Recovery, 1933-1936: Does the Keynesian Interpretation Still Hold?” Mimeo.

Romer, C. 1992.”What Ended the Great Depression?” Journal of Economic History 52: 757784.

Romer, C. and D. Romer. 2009. "The Macroeconomic Effects of Tax Changes: Estimates Based on a New Measure of Fiscal Shocks.” American Economic Review, forthcoming.

Schön, L. 2007. En modern svensk ekonomisk historia. Tillväxt och omvandling under två sekel, 2nd edition. Stockholm: SNS forlag.

Tanaka, K. 2009. “Trade Collapse and Vertical Foreign Direct Investment.” http://www.voxeu.org/index.php?q=node/3537

Temin, P. 1989. Lessons from the Great Depression. Cambridge MA: MIT Press.

Uhlig, H. 2005. "What are the Effects of Monetary Policy on Output? Results from an Agnostic Identification Procedure.” Journal of Monetary Economics 52: 381-419.

United Nations. 1962. International Trade Statistics 1900-1960. Mimeo, MGT(62)12 (May). Available at http://unstats.un.org/unsd/trade/imts/historical_data.htm 
Wagenführ, R. 1933. “Die Industriewirtschaft: Entwicklungstendenzen der deutschen und internationalen Industrieproduktion 1860 bis 1932.” Vierteljahrshefte zur Konjunkturforschung: Sonderheft 31.

Yi, K.-M. 2009. “The Collapse of Global Trade: the Role of Vertical Specialization.” In Baldwin, R.E. and S. Evenett (eds), The collapse of global trade, murky protectionism, and the crisis: Recommendations for the G20. VoxEU:

http://www.voxeu.org/reports/Murky_Protectionism.pdf 
Table 1: Panel Regressions. Dependent variable: change in log real GDP

\begin{tabular}{|c|c|c|c|c|c|c|c|c|}
\hline & \multicolumn{4}{|c|}{ OLS } & \multicolumn{4}{|c|}{ IV } \\
\hline & $\mathrm{FE}$ & $\mathrm{RE}$ & $\mathrm{FE}$ & $\mathrm{RE}$ & $\mathrm{FE}$ & $\mathrm{RE}$ & $\mathrm{FE}$ & $\mathrm{RE}$ \\
\hline \multirow[t]{2}{*}{ DG } & $0.057 * *$ & $0.056^{* *}$ & $0.053 * *$ & $0.054 * *$ & $0.195 * *$ & $0.194^{* *}$ & 0.154 & $0.229 * *$ \\
\hline & $(0.016)$ & $(0.016)$ & $(0.015)$ & $(0.014)$ & $(0.068)$ & $(0.065)$ & $(0.127)$ & $(0.067)$ \\
\hline \multirow[t]{2}{*}{$r$} & $-0.008 * *$ & -0.002 & -0.003 & 0.003 & $-0.015 * *$ & $-0.015^{* *}$ & -0.060 & 0.0142 \\
\hline & $(0.003)$ & $(0.002)$ & $(0.004)$ & $(0.002)$ & $(0.005)$ & $(0.004)$ & $(0.105)$ & $(0.009)$ \\
\hline \multirow[t]{2}{*}{ Constant } & $0.060 * *$ & $0.031^{* *}$ & $0.049 *$ & $0.028^{*}$ & $0.085^{* *}$ & $0.086 * *$ & 0.241 & -0.024 \\
\hline & $(0.013)$ & $(0.009)$ & $(0.019)$ & $(0.012)$ & $(0.022)$ & $(0.030)$ & $(0.379)$ & $(0.035)$ \\
\hline Year dummies & no & no & yes & yes & no & no & yes & yes \\
\hline Observations & 332 & 332 & 332 & 332 & 328 & 328 & 328 & 328 \\
\hline R-squared & 0.024 & 0.040 & 0.261 & 0.288 & 0.031 & 0.033 & 0.024 & 0.176 \\
\hline \multicolumn{9}{|c|}{$\begin{array}{l}\text { Notes: Panel formed by } 27 \text { countries in the period } 1925-1939 \text {. Standard errors are in } \\
\text { parenthesis. The statistical significance is }+ \text { significant at } 10 \% \text {; } * \text { significant at } 5 \% \text {; ** } \\
\text { significant at } 1 \% \text {. FE stands for fixed-effects estimation and RE stands for random-effects } \\
\text { estimation. In the IV models, DG and } r \text { are instrumented with the change in defence spending } \\
\text { and a gold standard dummy. }\end{array}$} \\
\hline
\end{tabular}




\begin{tabular}{|c|c|c|c|c|c|c|c|c|}
\hline GDP(t-1) & $0.80 * *$ & $0.73 * *$ & $0.81 * *$ & $0.73 * *$ & $0.81^{* *}$ & $0.76^{* *}$ & $0.82 * *$ & $0.76 * *$ \\
\hline & $(0.031)$ & $(0.037)$ & $(0.034)$ & $(0.040)$ & $(0.030)$ & (0.034) & $(0.032)$ & $(0.037)$ \\
\hline Fiscal shock \#1 & $\begin{array}{l}0.06 * * \\
(0.017)\end{array}$ & $\begin{array}{l}0.05 * * \\
(0.015)\end{array}$ & & & $\begin{array}{l}0.05 * * \\
(0.015)\end{array}$ & $\begin{array}{l}0.04 * * \\
(0.014)\end{array}$ & & \\
\hline Fiscal shock \#2 & & & $\begin{array}{l}0.06 * * \\
(0.018)\end{array}$ & $\begin{array}{l}0.06 * * \\
(0.016)\end{array}$ & & & $\begin{array}{l}0.06^{* *} \\
(0.016)\end{array}$ & $\begin{array}{l}0.05^{* *} \\
(0.015)\end{array}$ \\
\hline$r$ & $\begin{array}{l}-0.02 * * \\
(0.003)\end{array}$ & $\begin{array}{l}-0.01^{*} \\
(0.004)\end{array}$ & $\begin{array}{l}-0.02 * * \\
(0.003)\end{array}$ & $\begin{array}{l}-0.01+ \\
(0.005)\end{array}$ & $\begin{array}{l}-0.01 * * \\
(0.003)\end{array}$ & $\begin{array}{l}-0.01+ \\
(0.004)\end{array}$ & $\begin{array}{l}-0.01 * * \\
(0.003)\end{array}$ & $\begin{array}{l}-0.01+ \\
(0.004)\end{array}$ \\
\hline Cons. & $\begin{array}{l}1.04^{* *} \\
(0.152)\end{array}$ & $\begin{array}{l}1.37 * * \\
(0.180)\end{array}$ & $\begin{array}{l}0.99 * * \\
(0.165)\end{array}$ & $\begin{array}{l}1.37 * * \\
(0.197)\end{array}$ & $\begin{array}{l}0.97^{* *} \\
(0.144)\end{array}$ & $\begin{array}{l}1.20 * * \\
(0.166)\end{array}$ & $\begin{array}{l}0.95^{* *} \\
(0.156)\end{array}$ & $\begin{array}{l}1.19 * * \\
(0.176)\end{array}$ \\
\hline Obs. & 332 & 332 & 306 & 306 & 347 & 347 & 321 & 321 \\
\hline R-sq. & 0.80 & 0.85 & 0.78 & 0.84 & 0.80 & 0.85 & 0.78 & 0.84 \\
\hline Year dummies & no & yes & no & yes & no & yes & no & yes \\
\hline Multiplier & 0.39 & 0.35 & 0.39 & 0.39 & 2.24 & 1.74 & 2.44 & 1.90 \\
\hline
\end{tabular}

Notes: Panel formed by 27 countries in the period 1925-1939. Standard errors are in parenthesis. The statistical significance is + significant at $10 \%$; * significant at $5 \%$; ** significant at $1 \%$. All models are estimated by OLS and include country fixed effects. GDP(t-1) is the lagged value of GDP. Fiscal shock \#1 are the residuals of an AR(1) for the considered fiscal variable, while Fiscal shock \#2 are the residuals from and $A R(2)$ process. $r$ is the central bank discount rate. 


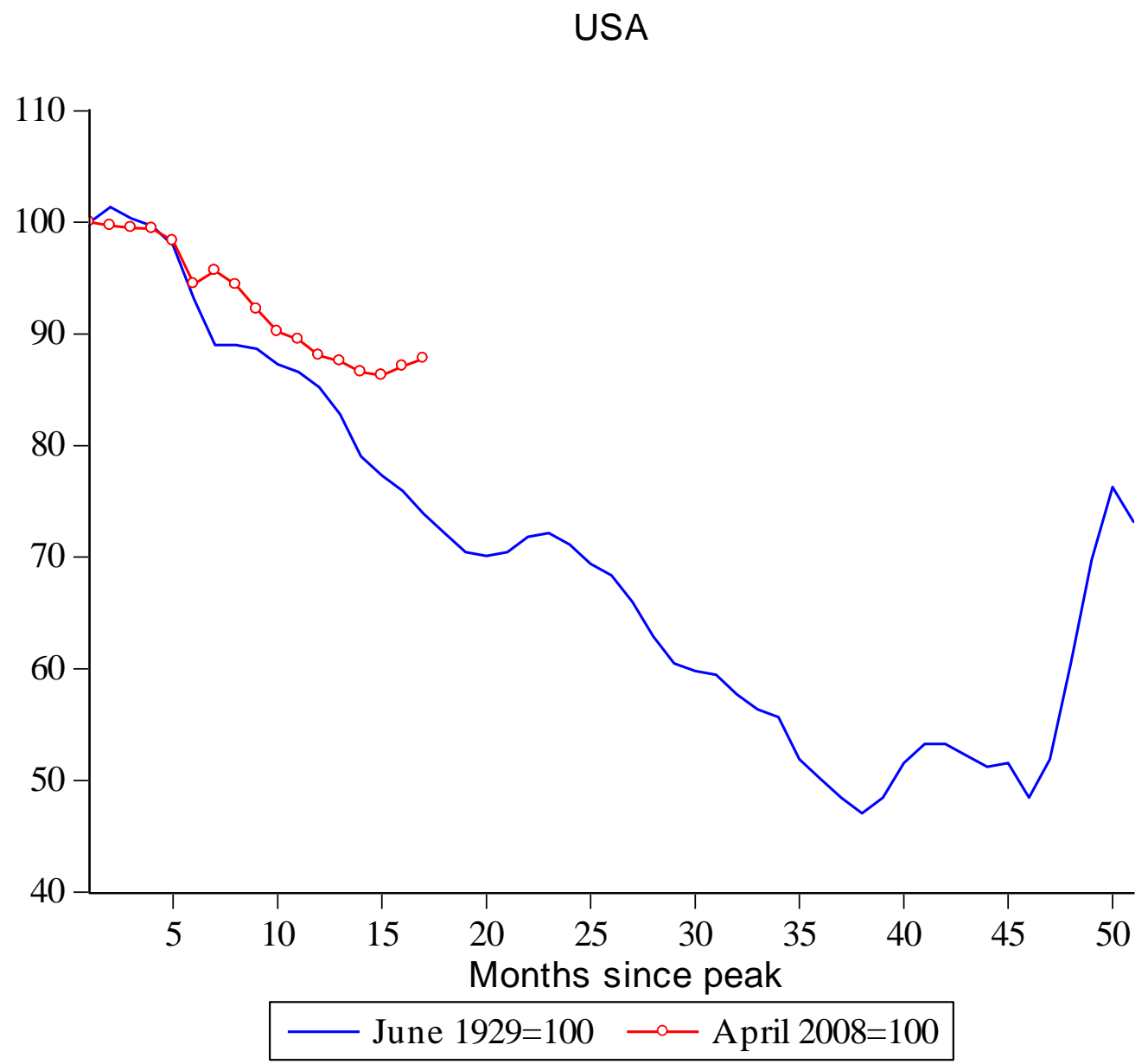

Figure 1. US Industrial Production, Now vs Then

Source : http://research.stlouisfed.org/fred2/series/INDPRO/downloaddata?rid=13 


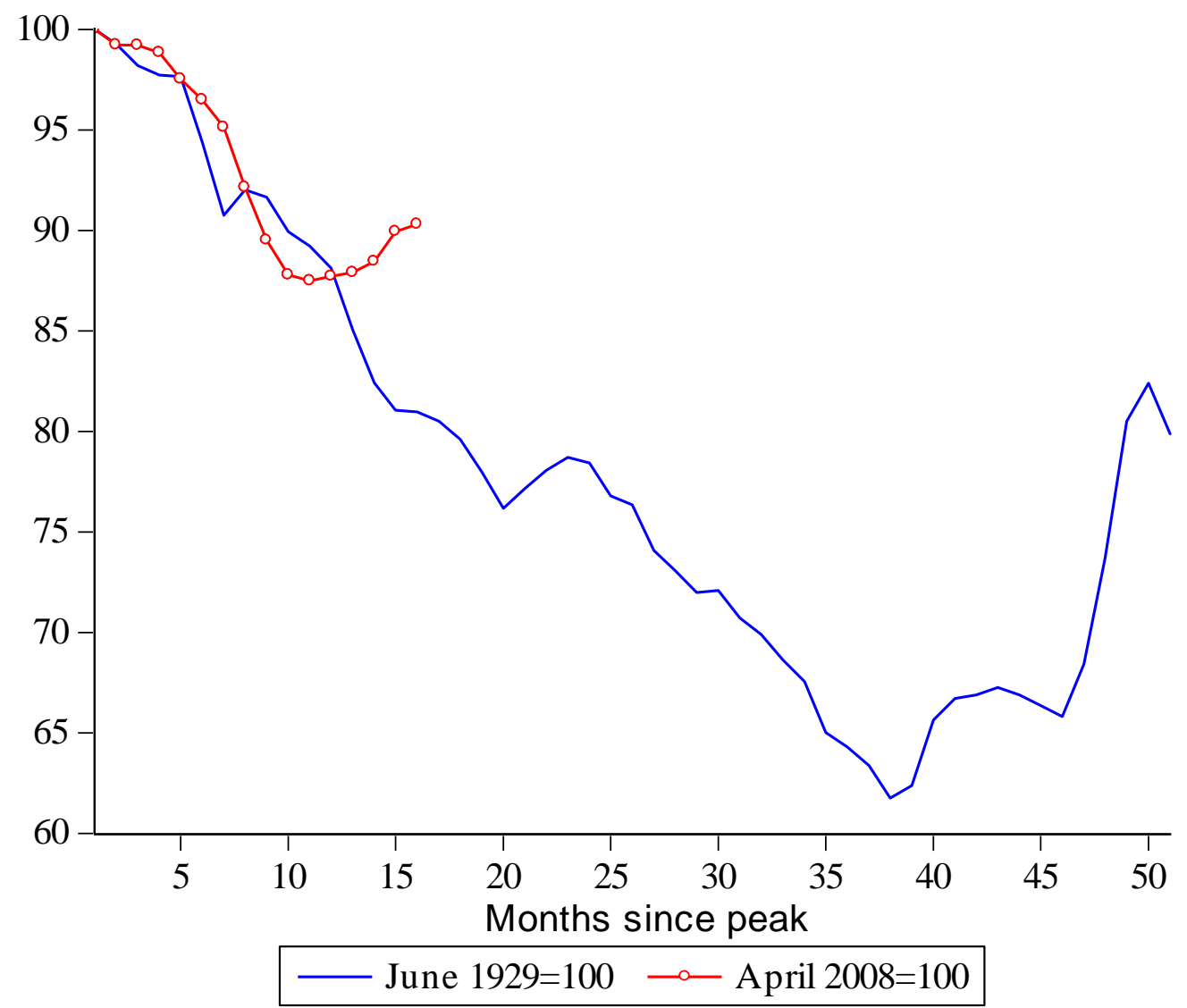

Figure 2. World Industrial Output, Now vs Then

Sources: Wagenführ (1933), Vierteljahrshefte zur Konjunkturforschung (various issues), Statistik des In-und Auslands (various issues). 


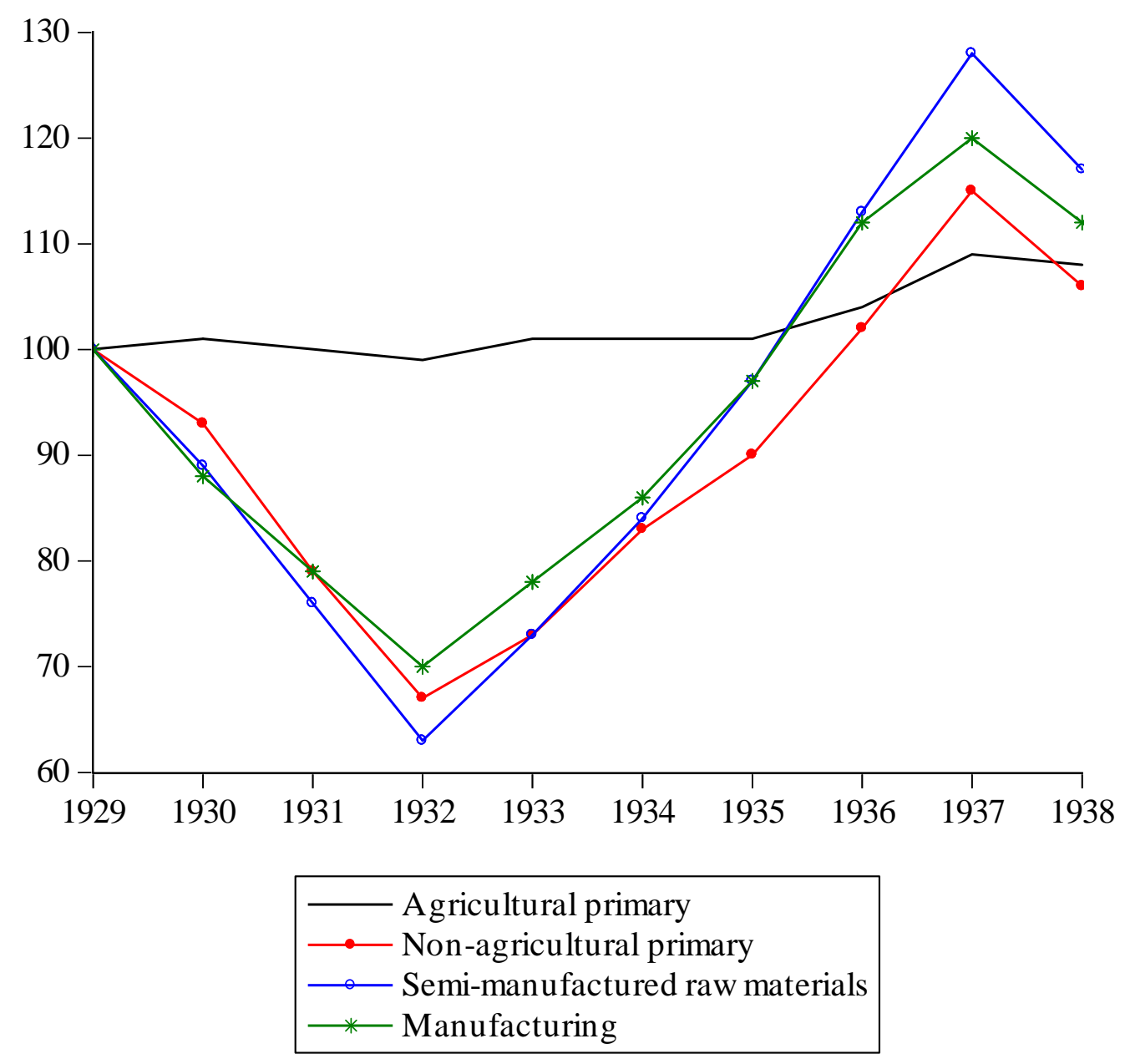

Figure 3. World Output, 1929-1938 $(1929=100)$

Source: League of Nations (1939). 


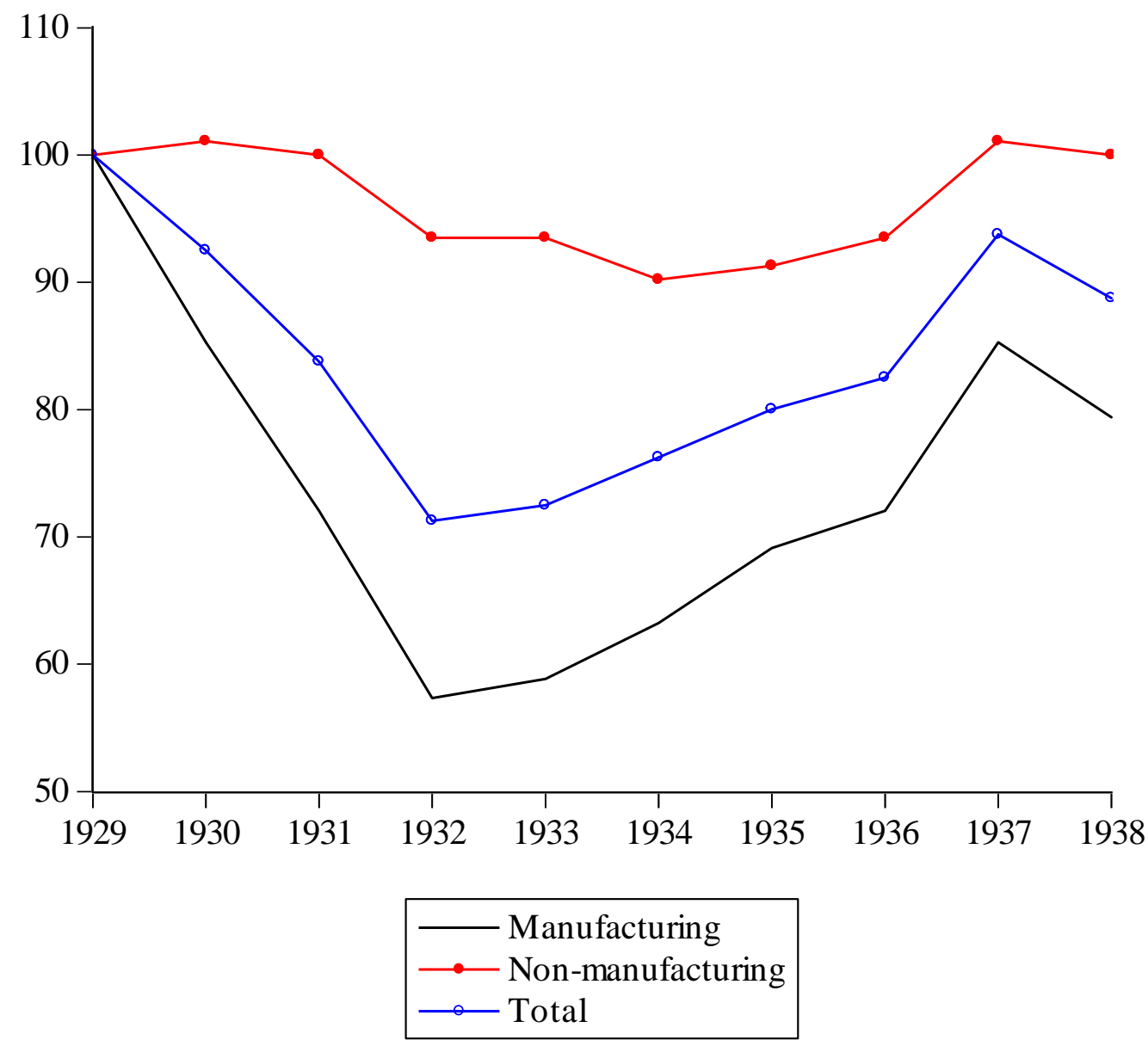

Figure 4. World Trade, 1929-1938 (1929=100)

Source: United Nations (1962). 


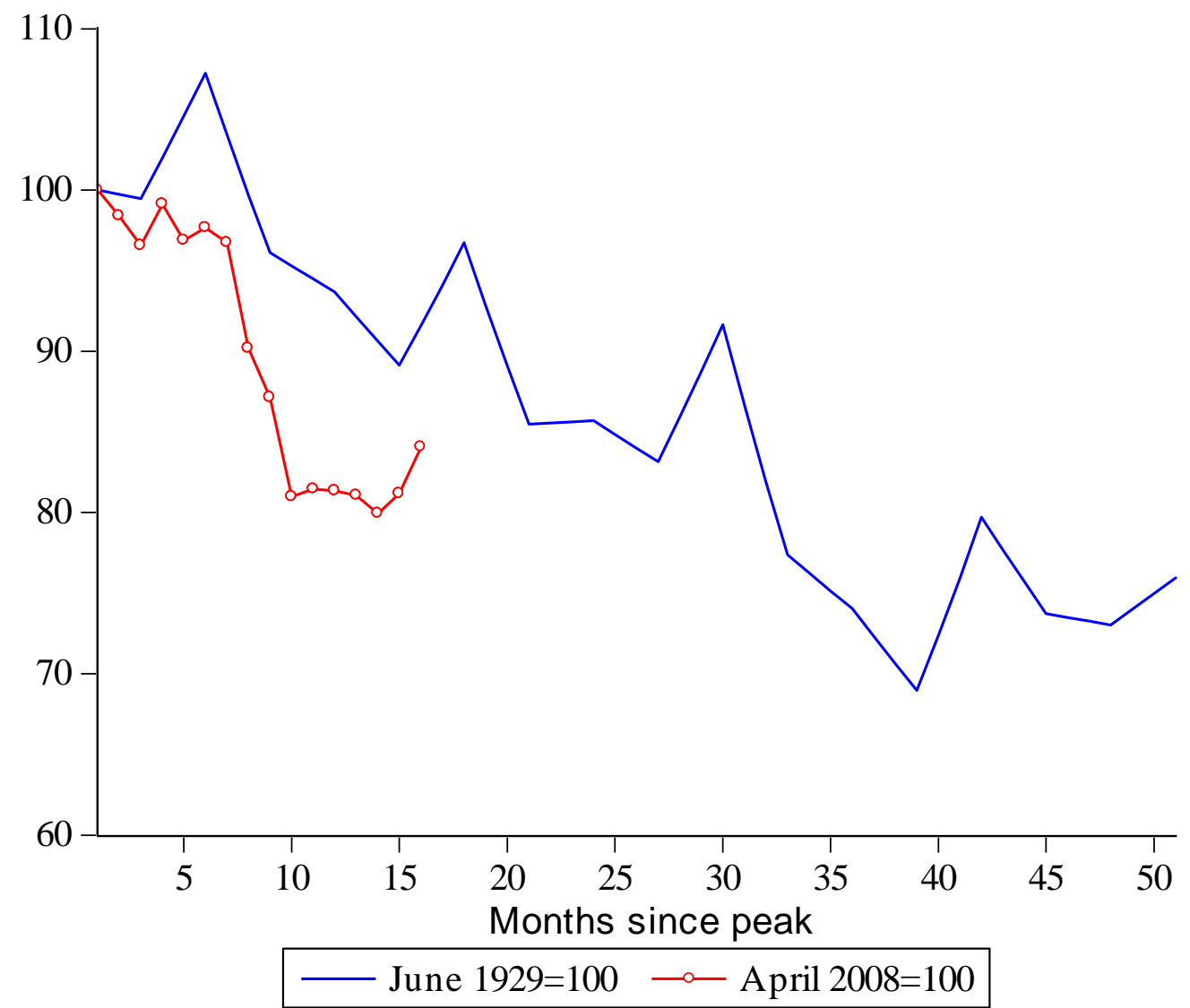

Figure 5. The Volume of World Trade, Now vs Then

Sources: League of Nations Monthly Bulletin of Statistics,

http://www.cpb.nl/eng/research/sector2/data/trademonitor.html 


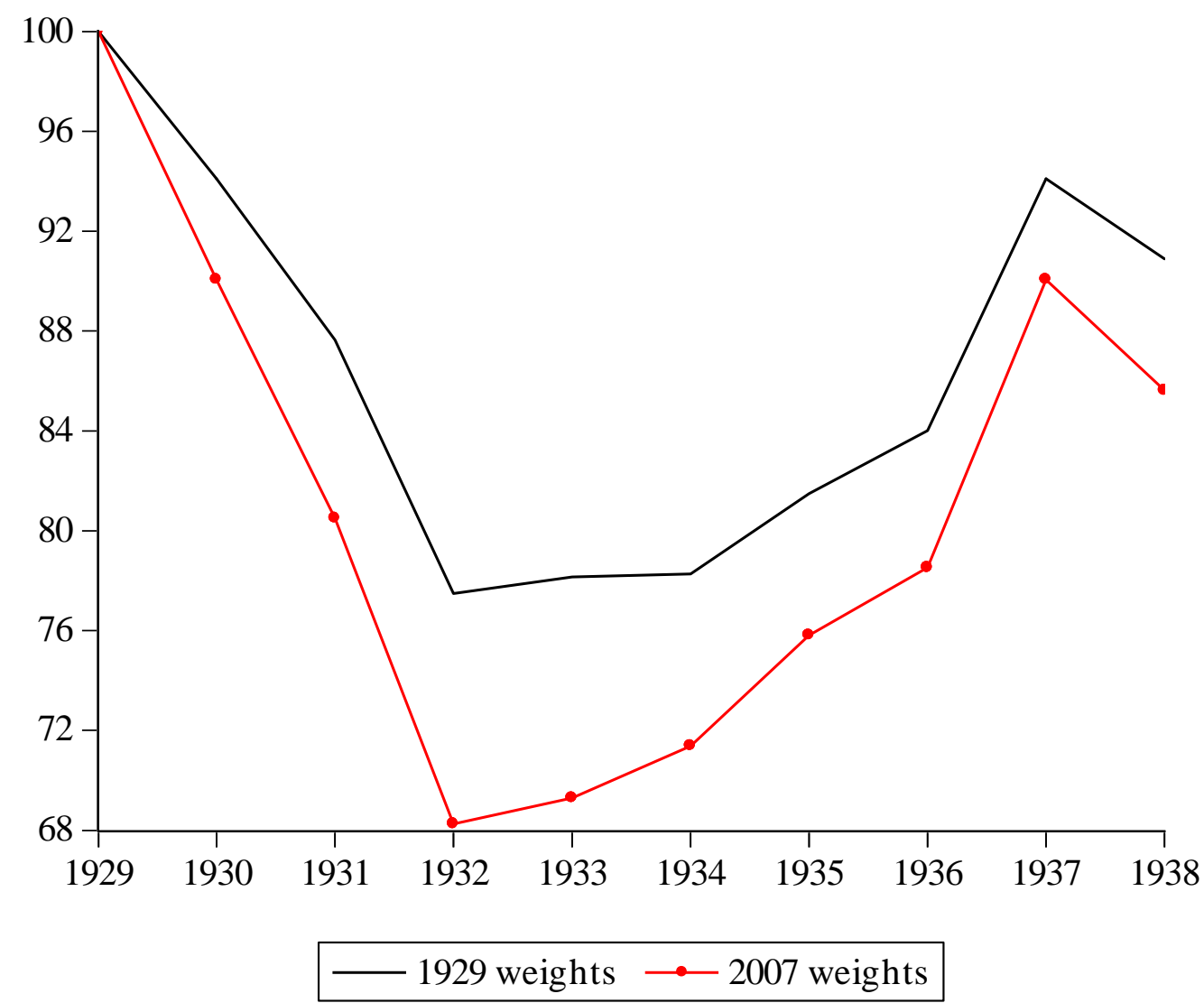

Figure 6. The Composition and Volume of World Trade

Source: see text. 


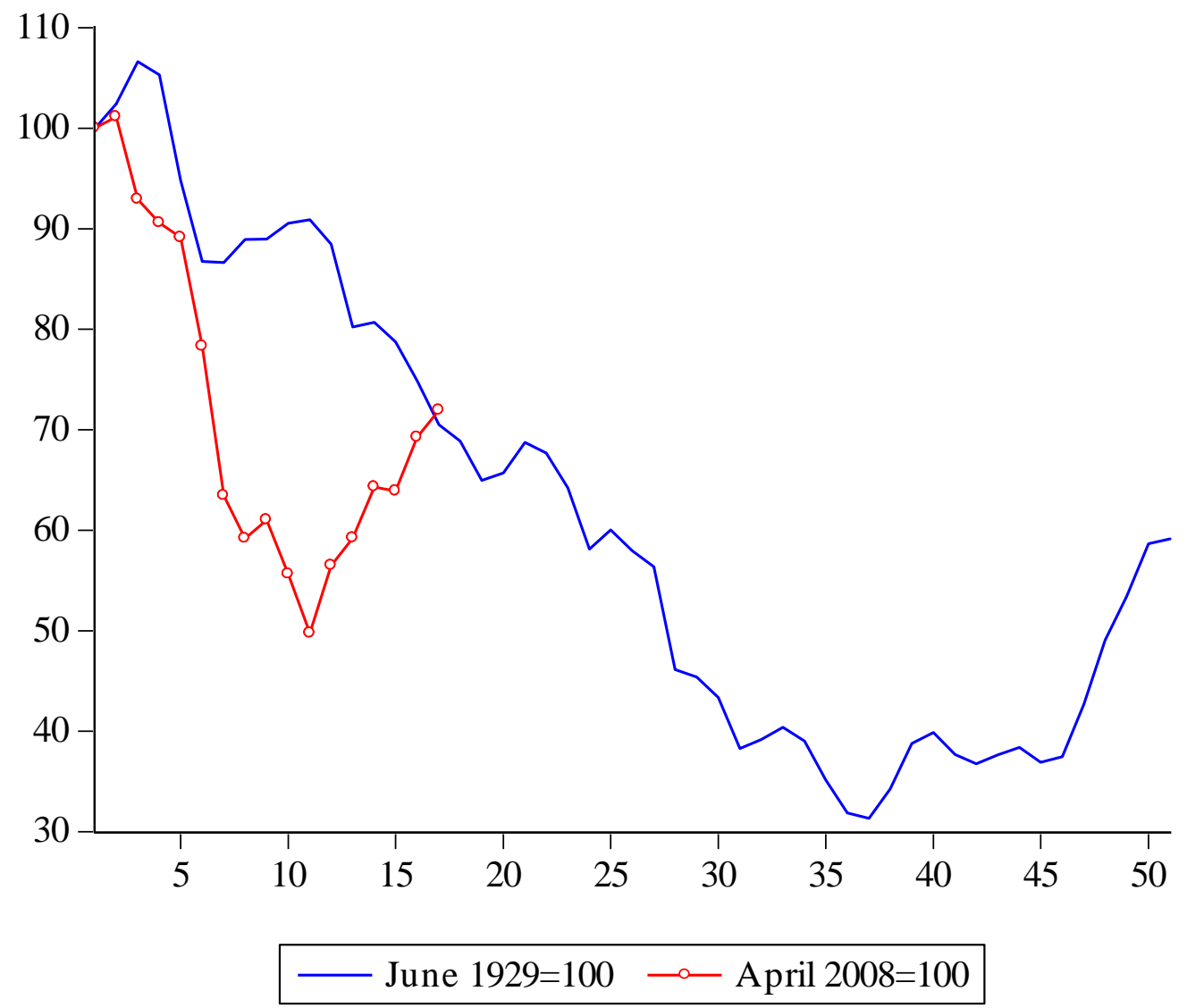

Figure 7. World Stock Markets, Now vs Then

Source: Global Financial Database. 

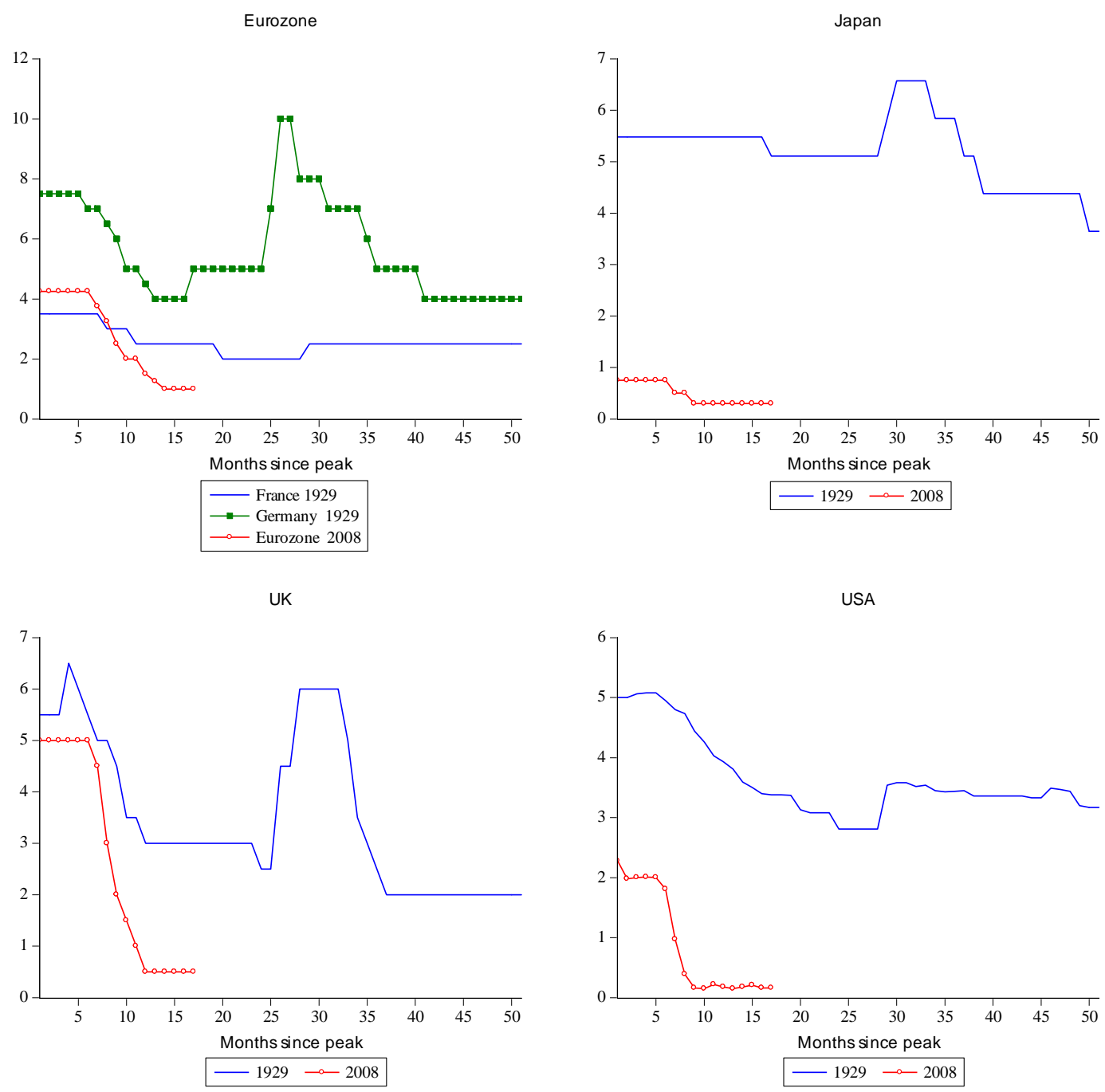

Figure 8. Central Bank Discount Rates, Now vs Then

Source: Bernanke and Mihov (2000), Bank of England, ECB, Bank of Japan, St. Louis Fed. 


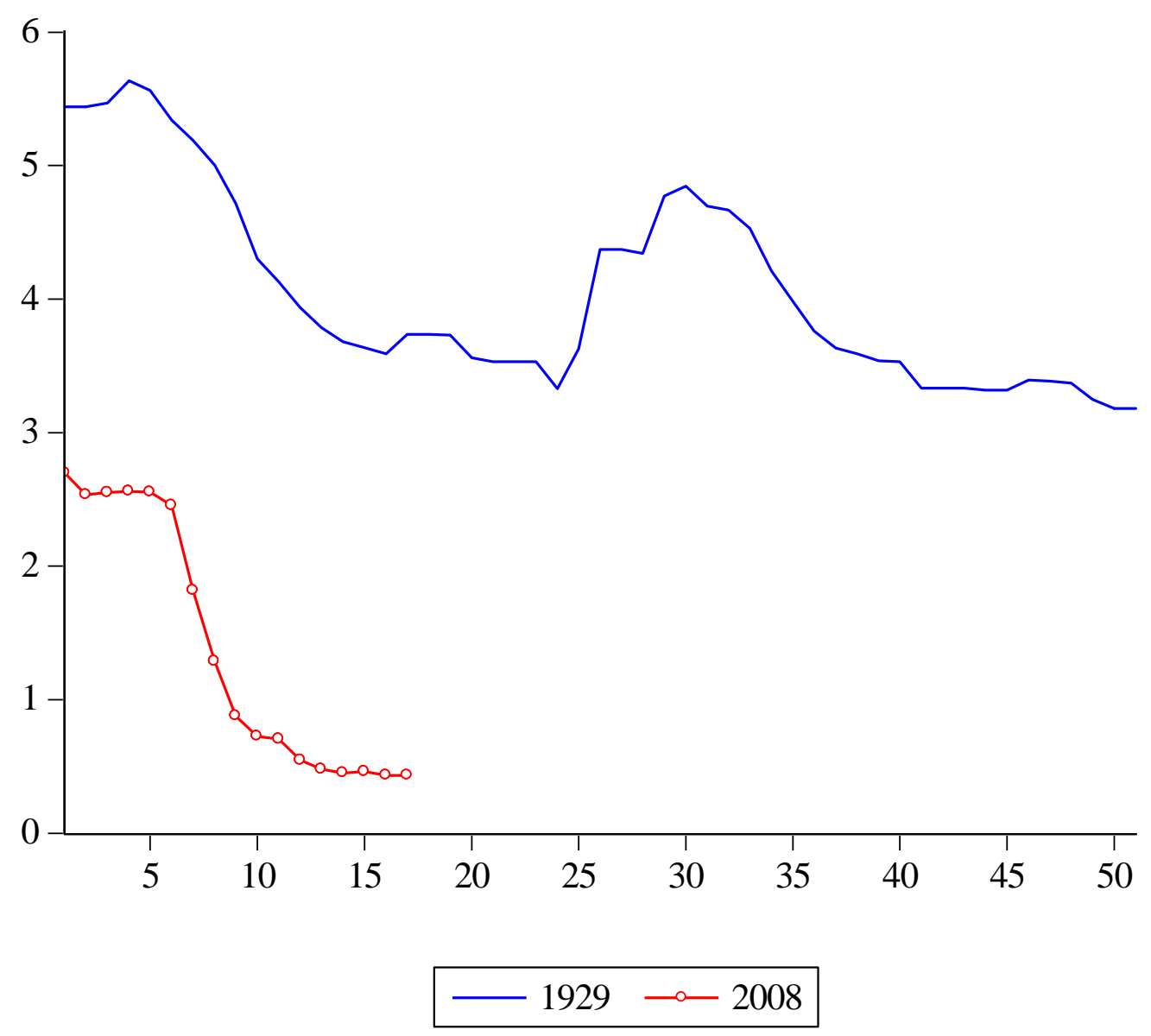

Figure 9. Central Bank Discount Rates, Now vs Then (7 country average)

Source: Bernanke and Mihov (2000); Bank of England, ECB, Bank of Japan, St. Louis Fed, National Bank of Poland, Sveriges Riksbank. 


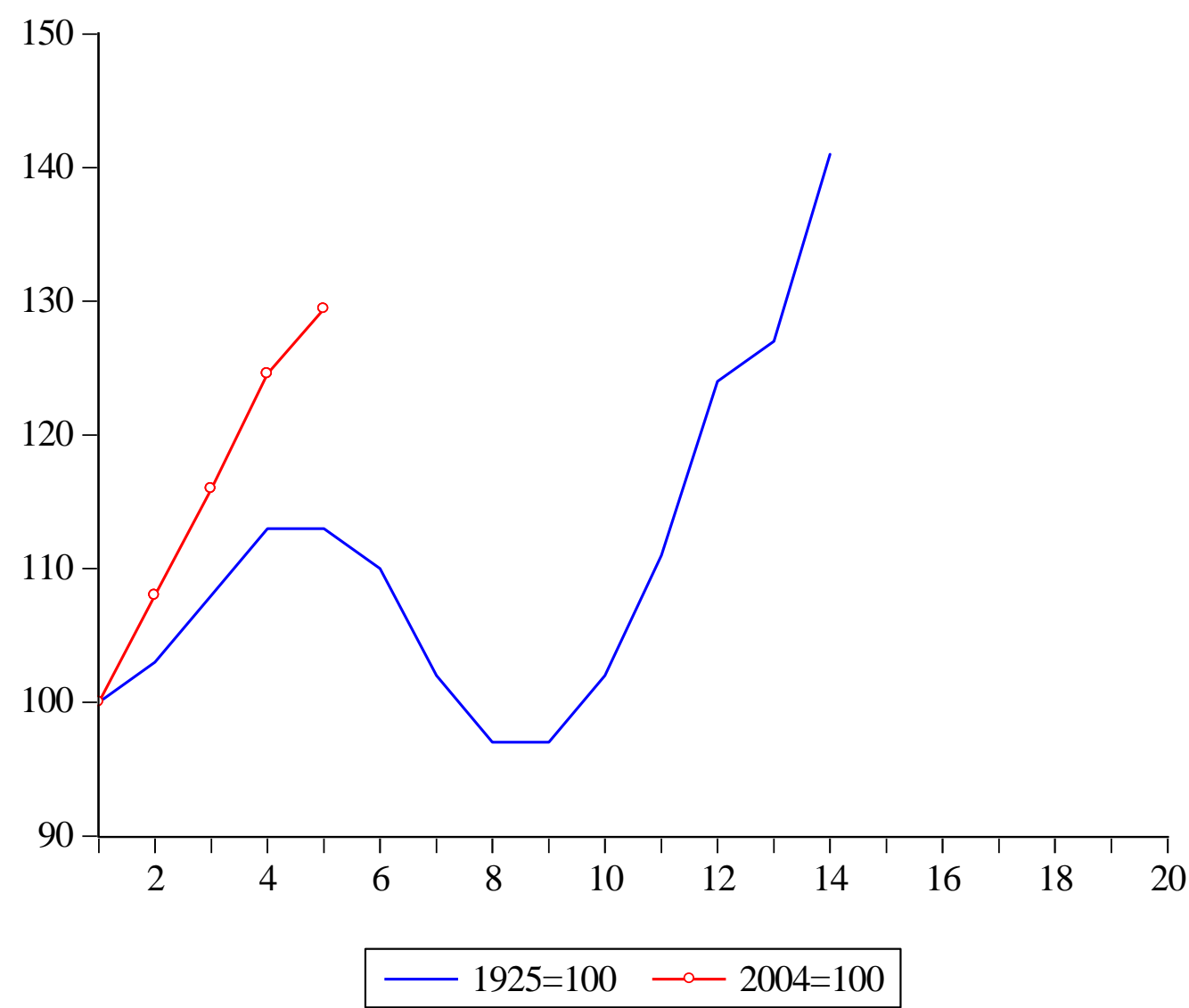

Figure 10. Money Supplies, 17 Countries, Now vs Then

Source: IMF International Financial Statistics, OECD Monthly Economic Indicators, and the data sources listed in Appendix 1. 


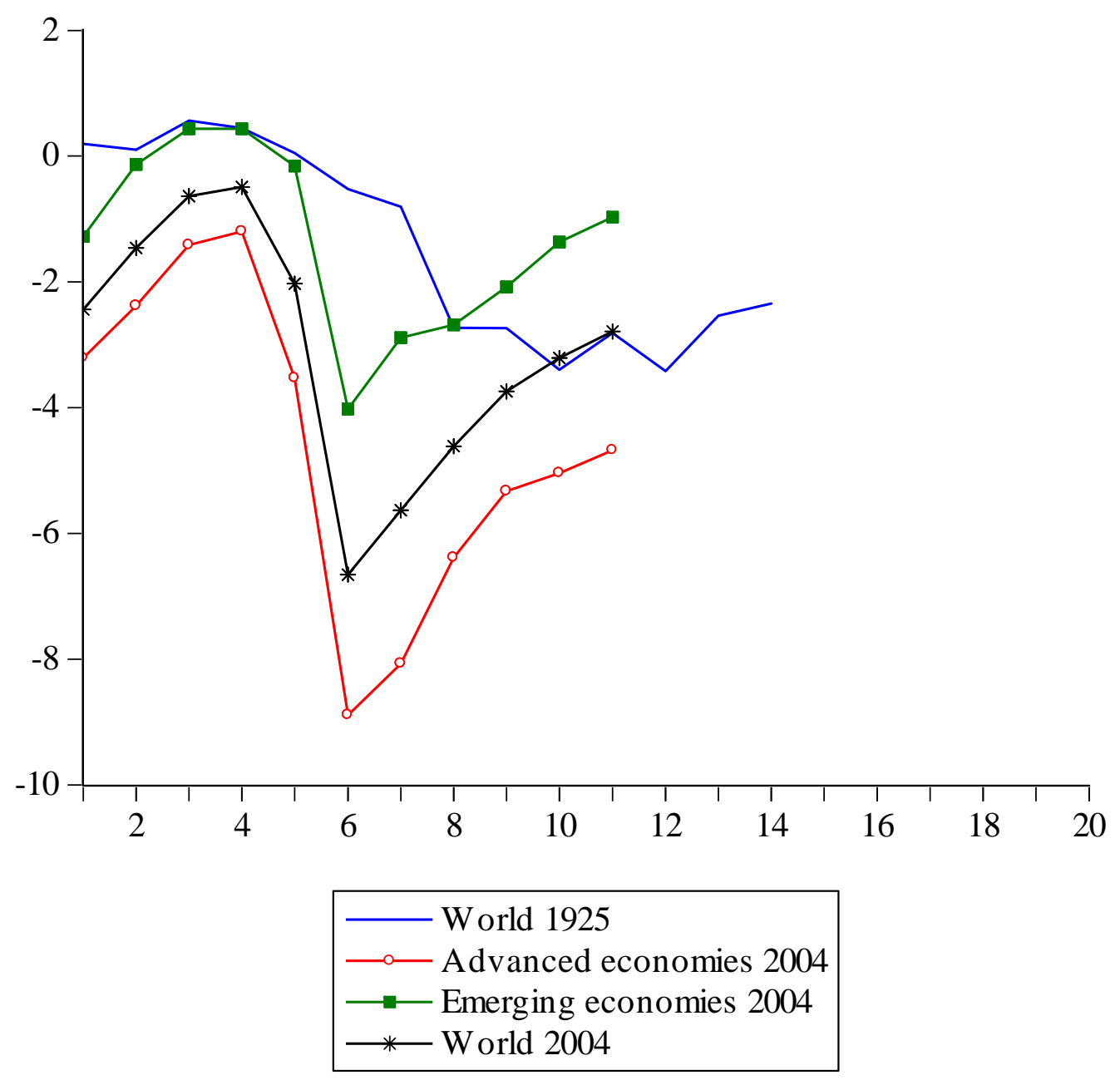

Figure 11. Government Budget Surpluses, Now vs Then

Source: IMF World Economic Outlook, October 2009, and the data sources listed in Appendix 1.

Notes: interwar data are a GDP-weighted average for 20 countries; current data are for the world as a whole. 


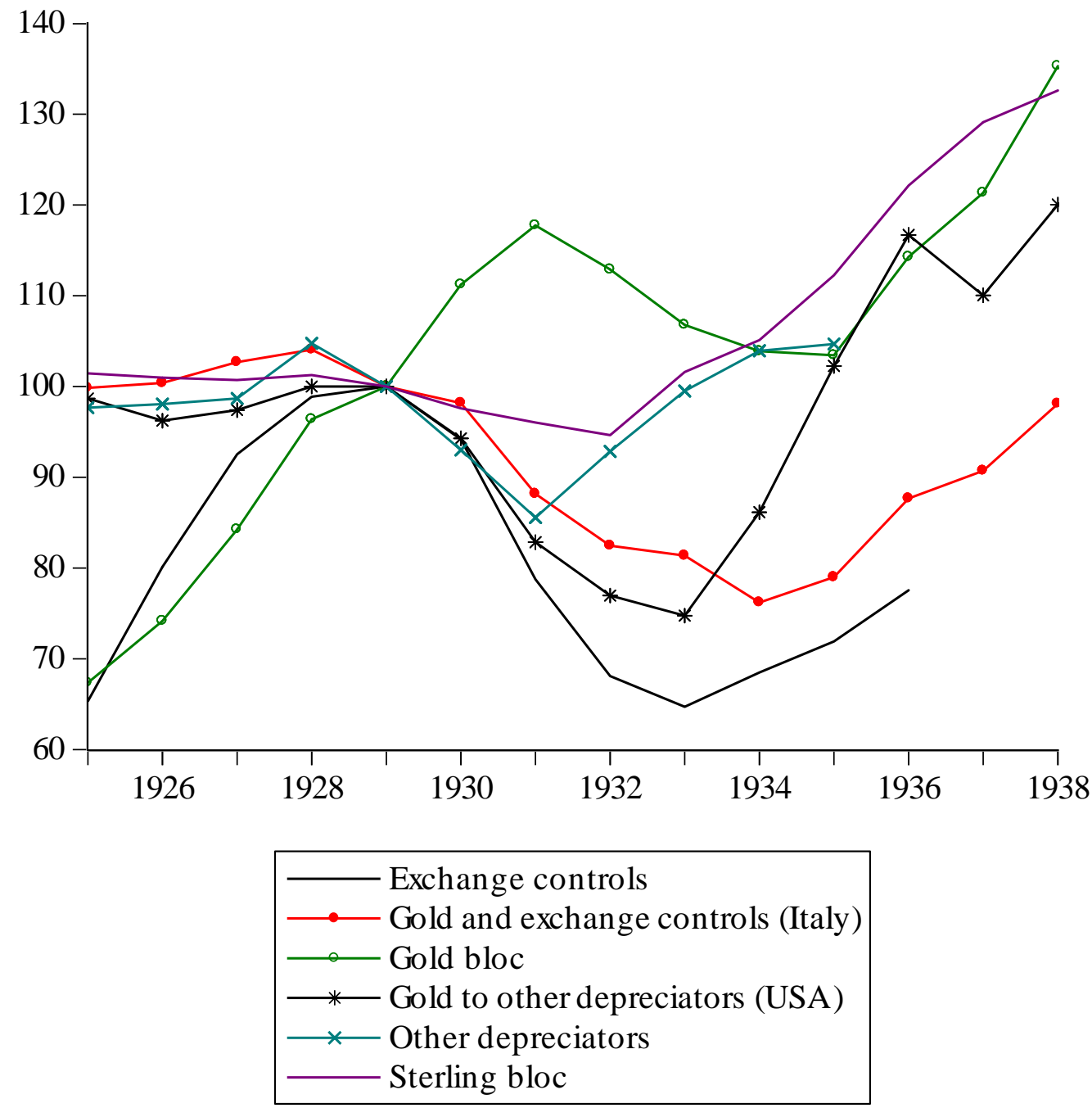

Figure 12. Interwar Money Supplies, by Exchange Rate Regime

Source: see Appendix 1. 


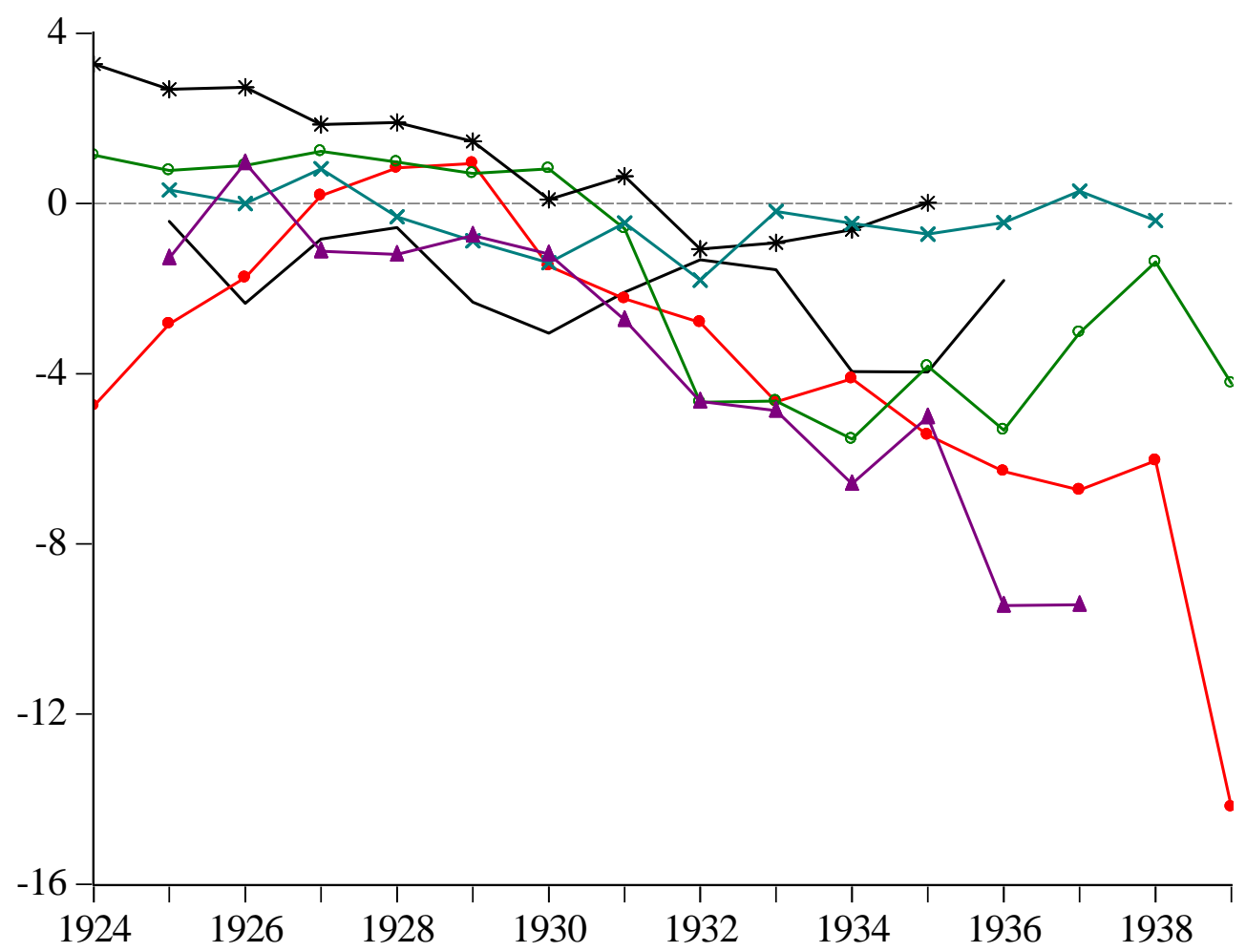

Exchange controls

$\longrightarrow$ Gold bloc

— Gold to other depreciators (USA)

* Other depreciators

× Sterling bloc

$\longrightarrow$ Gold and exchange controls

Figure 13. Interwar Government Budget Surpluses, by Exchange Rate Regime

Source: see Appendix 1. 

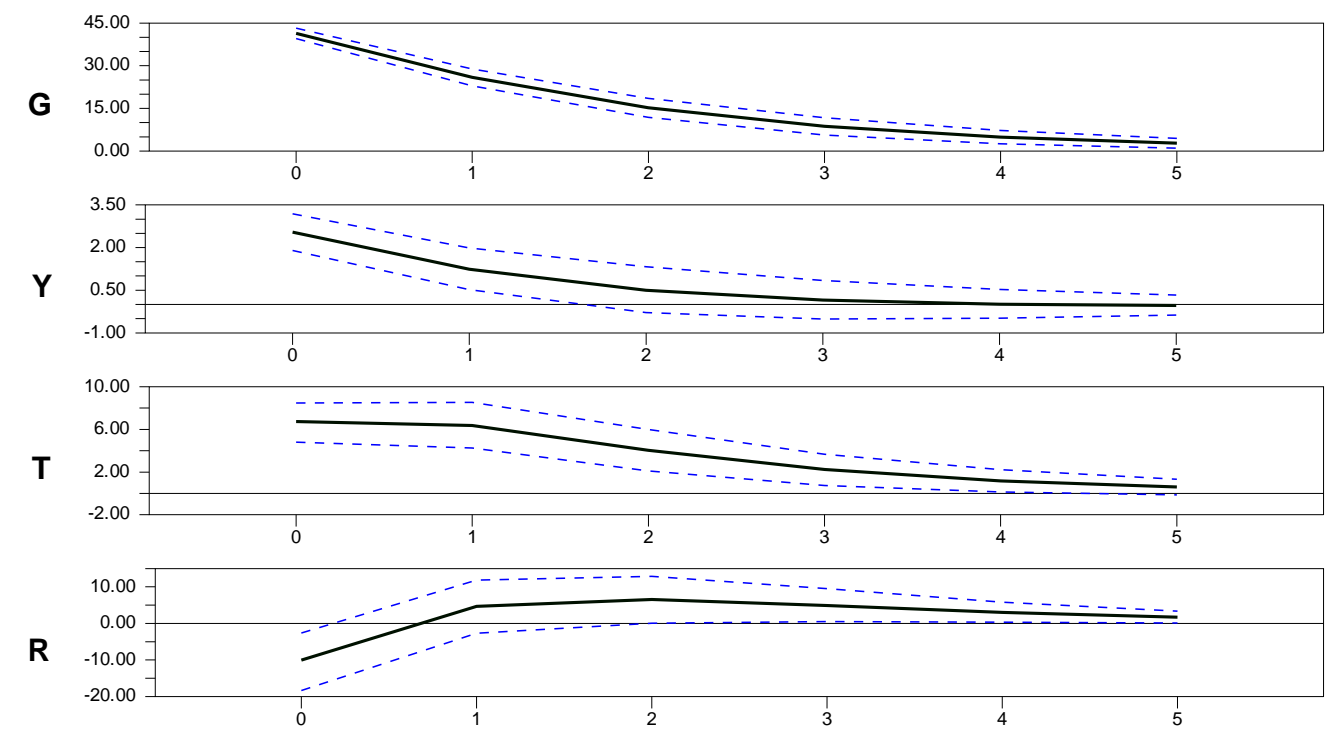

Figure 14. Impulse response functions, shock to defence spending (1\% of GDP)

Note: Solid lines are the point estimates of the impulse-response mean. Dashed lines are the 16th and 84th percentiles from Monte Carlo simulations based on 1000 replications. Vertical axis indicates defence spending (G), GDP (Y), revenues (T) and central bank discount rate (R). Each equation in the system includes country fixed effects, country-specific linear trends and year dummies. 

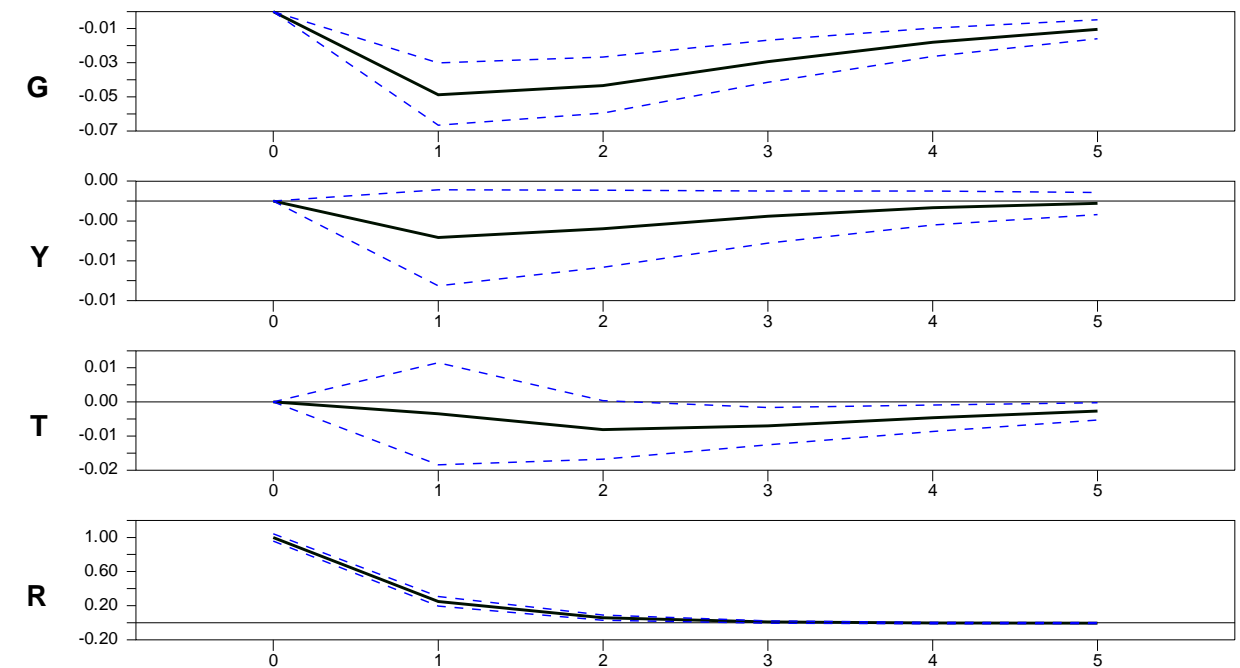

Figure 15. Impulse response functions, shock to discount rate

Note: Solid lines are the point estimates of the impulse-response mean. Dashed lines are the 16th and 84th percentiles from Monte Carlo simulations based on 1000 replications. Vertical axis indicates defence spending (G), GDP (Y), revenues (T) and central bank discount rate $(\mathrm{R})$. Each equation in the system includes country fixed effects, country-specific linear trends and year dummies. 

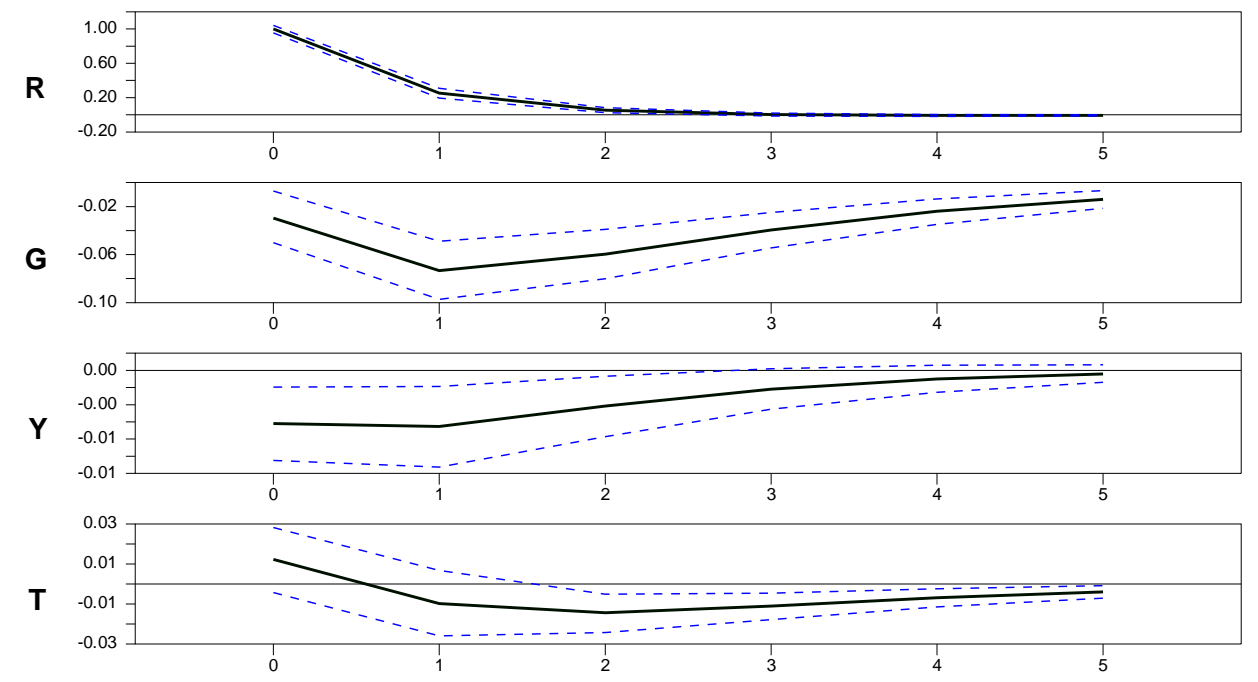

Figure 16. Impulse response functions, shock to discount rate (alternative ordering)

Note: Solid lines are the point estimates of the impulse-response mean. Dashed lines are the 16th and 84th percentiles from Monte Carlo simulations based on 1000 replications. Vertical axis indicates defence spending (G), GDP (Y), revenues (T) and central bank discount rate $(R)$. Each equation in the system includes country fixed effects, country-specific linear trends and year dummies. 

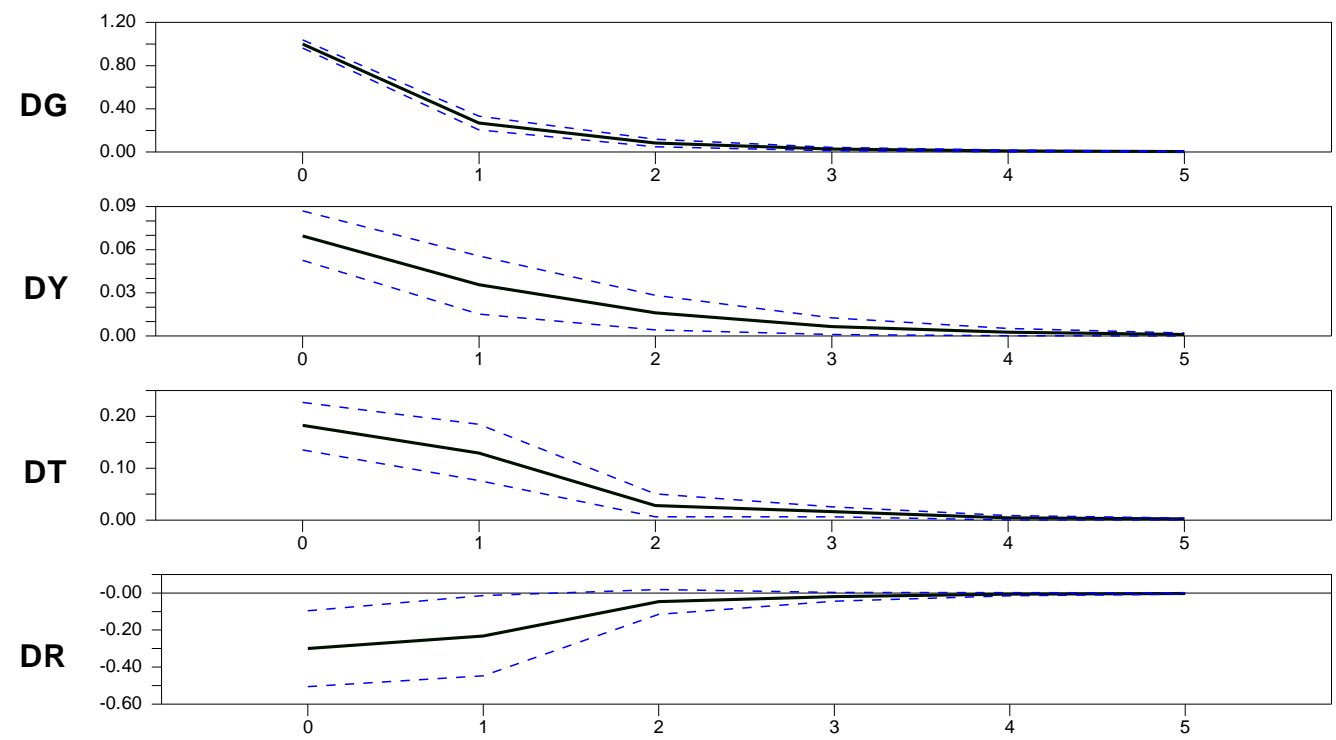

Figure 17. Impulse response functions, shock to change in defence spending. Model in Differences.

Note: Solid lines are the point estimates of the impulse-response mean. Dashed lines are the 16th and 84th percentiles from Monte Carlo simulations based on 1000 replications. Vertical axis indicates the change in: defence spending (DG), GDP (DY), revenues (DT) and central bank discount rate (DR). 

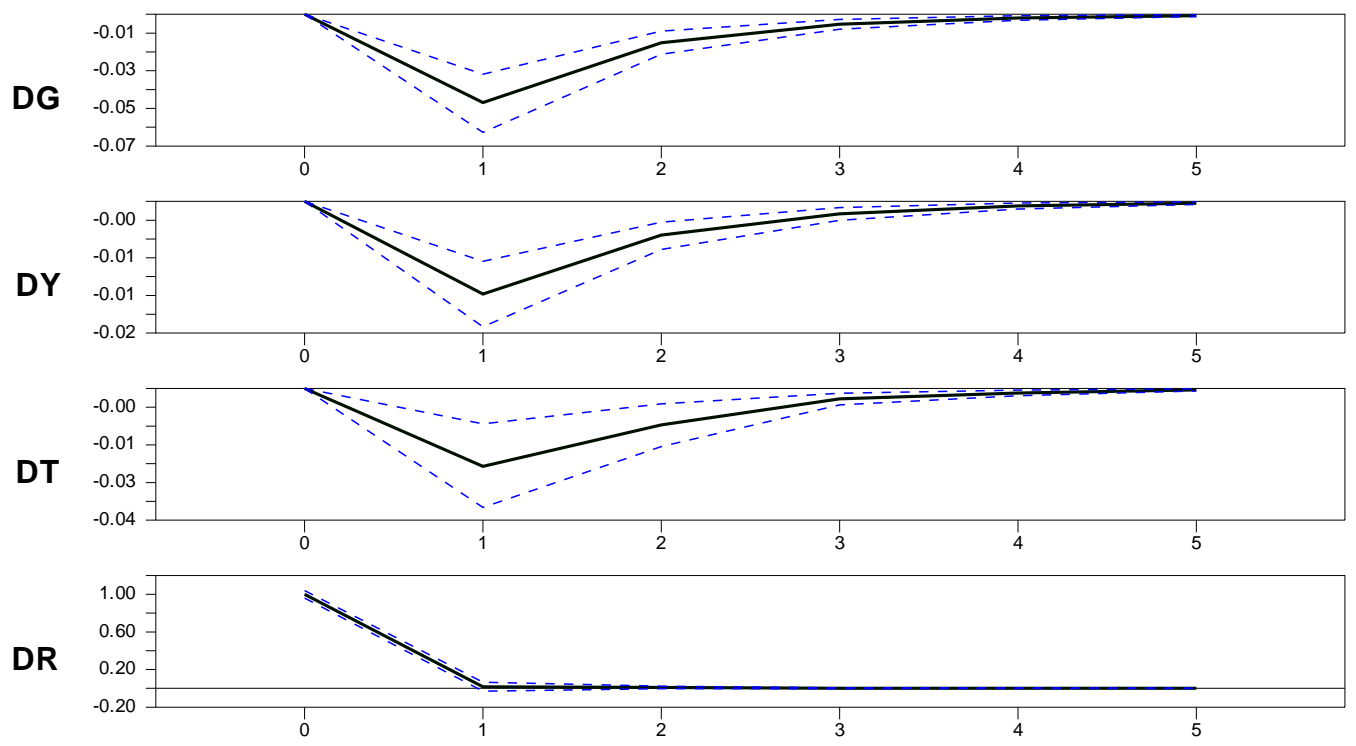

Figure 18. Impulse response functions, shock to change in discount rate. Model in Differences.

Note: Solid lines are the point estimates of the impulse-response mean. Dashed lines are the 16th and 84th percentiles from Monte Carlo simulations based on 1000 replications. Vertical axis indicates the change in: defence spending (DG), GDP (DY), revenues (DT) and central bank discount rate (DR). 

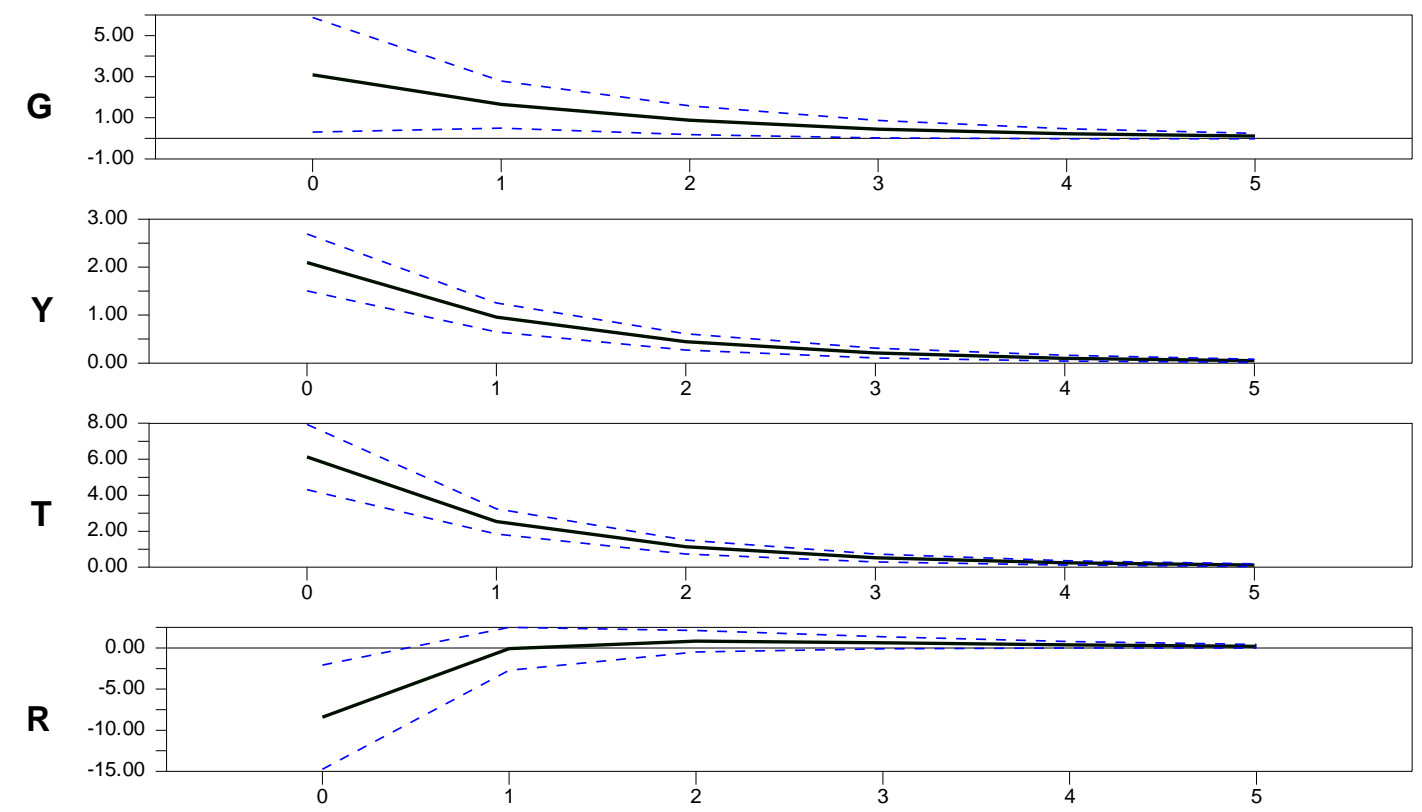

Figure 19. Impulse response functions, shock to defence spending (1\% of GDP)

Note: Defence spending is included as exogenous variable in each equation of the system. Solid lines are the point estimates of the impulse-response mean. Dashed lines are the 16th and 84th percentiles from Monte Carlo simulations based on 1000 replications. Vertical axis indicates: total government spending minus defence spending (G), GDP (Y), revenues (T) and central bank discount rate (R). 


\section{Appendix 1. Data sources}

\section{Monetary data: $\mathrm{M1}$}

1.1. From Bordo's dataset (in millions, local currency)

- Argentina: Domingo F. Cavallo and Yair Mundlak, Estadisticas de la evolucion economica de Argentina 1913-1984

- Belgium: M1, Statistical Appendix in J. Delbeke (1988), Geld en Bankkrediet in Belgie, 1877-1983, Klasse der Letteren, Jaargang 50, Nr. 129, Brussel: Koninklijke Academie voor Wetenschappen, Letteren en Schone Kunsten van Belgie, table 1.2, column 7 and table 1.3, column 9

- Brazil: IBGE (1990), Estatisticas Historicas do Brasil: Series Economicas, Demograficas e Sociais de 1550 a 1988 (Rio de Janeiro: IBGE)

- Netherlands: B. R. Mitchell (1992)

- Portugal: Economic History of Portugal, 1994, Eugenia Mata and Nuno Valerio (Presença, Lisbon)

- Spain: Historical Statistics of Spain, Siglos XIX-XX, 1989 (Fundacion Banco Exterior)

1.2. From national sources:

- Austria: Schubert, A. (2006) The Credit-Anstalt Crisis of 1931. Cambridge.

- Australia: N.G. Butlin, "Comparative Economic Statistics: Australia, New Zealand, Britain, Canada and the United States," Resource Paper in Economic History, Research School for Social Sciences, Australian National University, June 1984.

- Canada: Metcalf, Cherie, Angela Redish and Ronald Shearer. New Estimates of the Canadian Money Stock, 1871-1967. Canadian Journal of Economics. (February 1998): $104-125$.

- France: Saint-Etienne, C. (1984) The Great Depression, 1929-1938: Lessons for the 1980s. Stanford.

- Germany: Kindly provided by Albrecht Ritschl.

- Italy: The author is Gaiotti, researcher at the Bank of Italy. It is not published yet. (see Gianni Toniolo's email to Barry)

- Japan: Asakura K. and Nishiyama C. (1974) A monetary analysis and history of the Japanese economy, 1868-1970. Tokyo, Japan.

- Norway: NorgesBank. http://www.norges-bank.no/Upload/Statistikk/HMS/c5.xls

- Switzerland: Swiss National Bank. (2007) Historical Time Series. Zurich, Switzerland. http://www.snb.ch/en/iabout/stat/statpub/histz/id/statpub_histz_actual 
- United Kingdom: BR Mitchell, British Historical Statistics, CUP 1988, p. 674

- United States: Friedman M. and Schwartz A. J. (1963) A Monetary History of the United States: 1870-1960. Princeton.

1.3. From the League of Nations/Mitchell (in millions, local currency):

- Bulgaria, Chile, Colombia, Czechoslovakia, Denmark, Ecuador, El Salvador, Finland, Greece, Hungary, India, Ireland, Korea, Mexico, New Zealand, Paraguay, South Africa, Sweden, Taiwan, Uruguay.

\section{Fiscal data}

- Italy: from Giorgio Fua (1969), Lo sviluppo economico in Italia, Franco Angeli: Milano 1969, Vol.III.

- Germany: Kindly provided by Albrecht Ritschl.

- Portugal: from Nuno Valério (2001), Portuguese Historical Statistics. Lisbon.

- Government surplus over gdp (gsugdp_Bordo) from Bordo's dataset (in percentages) for the following countries:

o Argentina, Australia, Belgium, Brazil, Canada, Denmark, Finland, France, Greece, Japan, Netherlands, Norway, Spain, Sweden, Switzerland, United Kingdom, United States.

- Government surplus from the League of Nations Yearbook (in millions, local currency) for the following countries:

o Austria, Bulgaria, Chile, Colombia, Czechoslovakia, Hungary, India, Mexico, New Zealand.

- Revenues and expenditures from the League of Nations Yearbook (in millions, local currency) for all countries except Italy, Germany and Portugal.

- Defence expenditures from League of Nations (1924-40, several issues). "Armaments Year-book: General and statistical information." Accessed in electronic format (pdf) online at: http://www.library.northwestern.edu/otcgi/digilib /llscgi60.exe

\section{Other variables}

- Real GDP (rgdp_M; in 1990 international GK\$): from Maddison's dataset - updated version March 2009. 
- $\quad$ Nominal GDP (ngdp; in millions, local currency):

o from Global Financial Data and Mitchell: Argentina, Australia, Austria, Brazil, Bulgaria, Canada, Chile, Colombia, Czechoslovakia, Denmark, Finland, France, Germany, Greece, Hungary, India, Italy, Japan, Mexico, Netherlands, New Zealand, Norway, Spain, Sweden, the UK and the US.

o from Bordo's dataset: Belgium, Portugal and Switzerland.

- Central Bank discount rates: from Global Financial Data (CBdiscount).

- Banking and currency crises: from Eichengreen, B. J. and Bordo, M. D. (2002) Crises Now and Then: What Lessons from the Last Era of Financial Globalization. NBER Working Paper No. W8716.

- Defence expenditures: League of Nations (1924-40, several issues). Armaments Yearbook: General and statistical information. Accessed in electronic format (pdf) online at: http://www.library.northwestern.edu/otcgi/digilib /llscgi60.exe 
Appendix 2. Interwar fiscal and monetary policy, by country

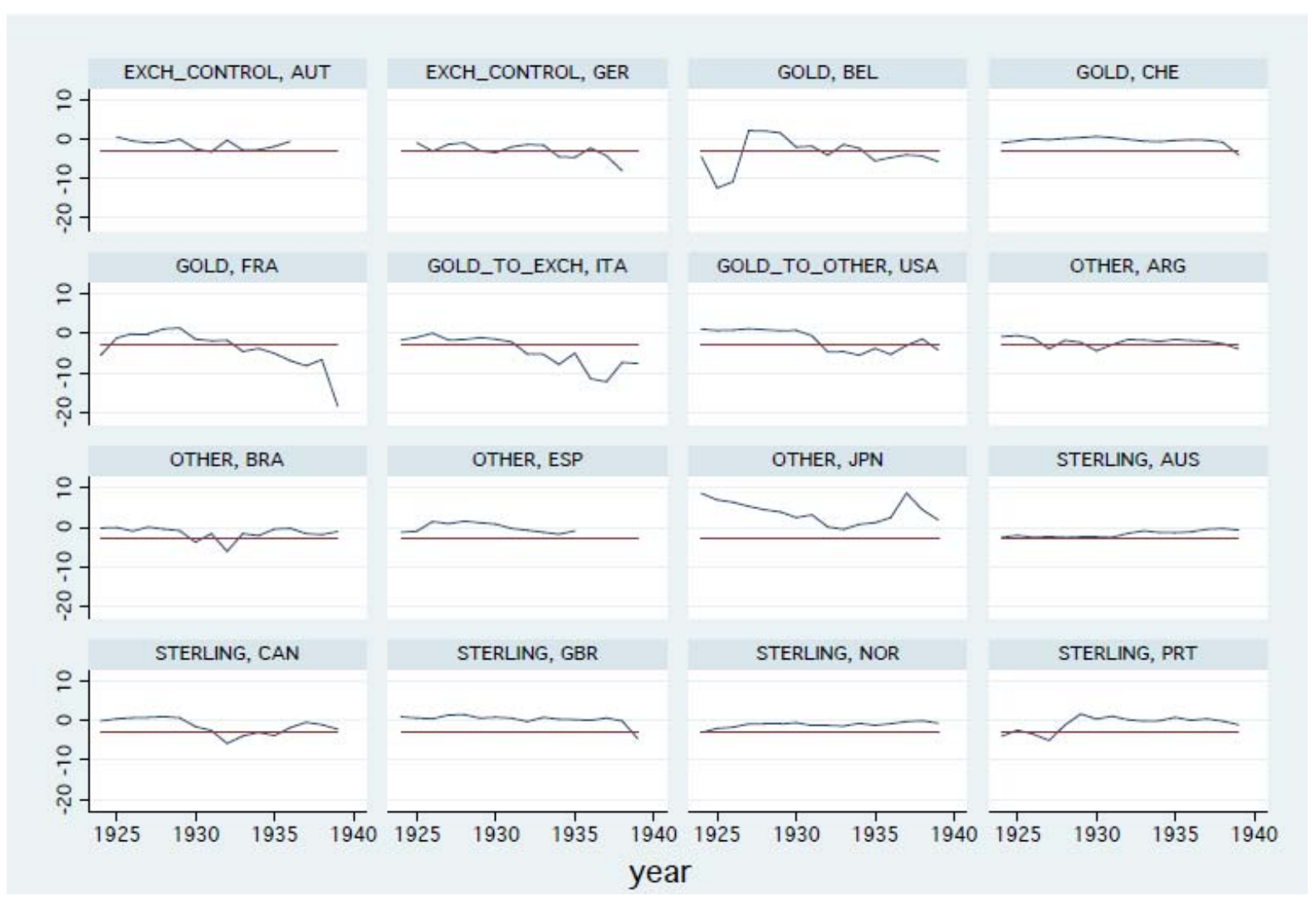

Appendix Figure 1. Budget deficits, by country

Source: see Appendix 1. 


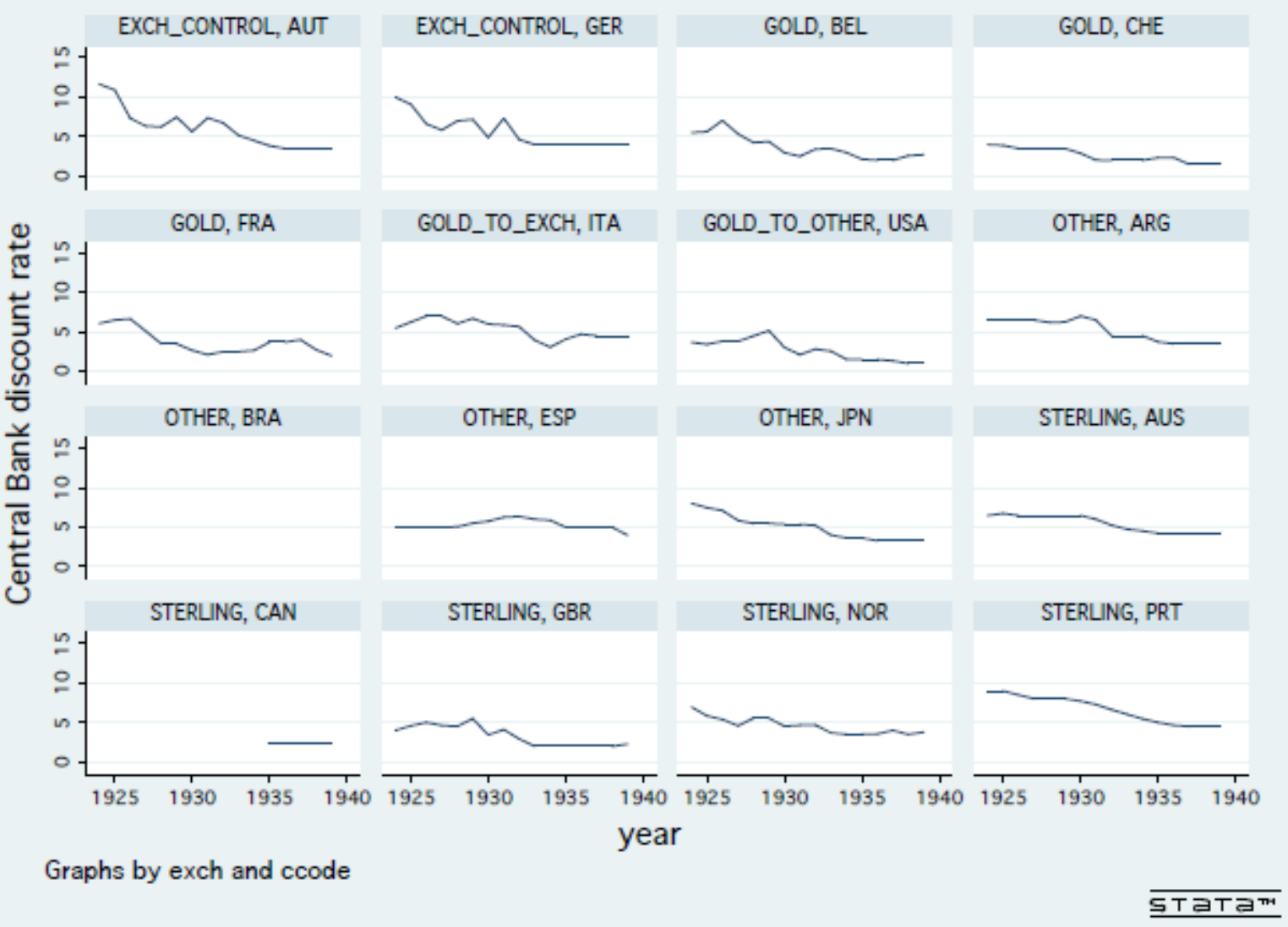

Appendix Figure 2. Discount rates, by country

Source: see Appendix 1. 